Article

\title{
Evaluation of Semi-Continuous Pit Manure Recharge System Performance on Mitigation of Ammonia and Hydrogen Sulfide Emissions from a Swine Finishing Barn
}

\author{
Jisoo Wi ${ }^{1} \mathbb{D}$, Seunghun Lee ${ }^{1}$, Eunjong $\operatorname{Kim}^{1}{ }^{1}$, Myeongseong Lee ${ }^{1} \mathbb{D}$, Jacek A. Koziel ${ }^{2, *(\mathbb{D})}$ \\ and Heekwon Ahn 1,* \\ 1 Department of Animal Biosystems Sciences, Chungnam National University, Daejeon 34134, Korea; \\ jswi@cnu.ac.kr (J.W.); huny9261@cnu.ac.kr (S.L.); ejkim0128@cnu.ac.kr (E.K.); leefame@cnu.ac.kr (M.L.) \\ 2 Department of Agricultural and Biosystems Engineering, Iowa State University, Ames, IA 50011, USA \\ * Correspondence: koziel@iastate.edu (J.A.K.); hkahn@cnu.ac.kr (H.A.); \\ Tel.: +1-515-294-4206 (J.A.K.); +82-042-821-5785 (H.A.)
}

Received: 10 February 2019; Accepted: 26 March 2019; Published: 30 March 2019

\begin{abstract}
In this research, for the first time, we present the evaluation of a semi-continuous pit manure recharge system on the mitigation of ammonia $\left(\mathrm{NH}_{3}\right)$ and hydrogen sulfide $\left(\mathrm{H}_{2} \mathrm{~S}\right)$ emissions from a swine finisher barn. The pit recharge system is practiced on many swine farms in the Republic of Korea, primarily for improving air quality in the barn. It consists of an integrated waste management system where the fraction of stored manure is pumped out $(10 \times$ of the daily production of manure, $3 \times$ a day); solids are separated and composted, while the aerobically treated liquid fraction is then returned to the pit. We compared emissions from two 240-pig rooms, one equipped with a pit recharge system, and the other operating a conventional slurry pit under the slatted floor. Mean reduction of $\mathrm{NH}_{3}$ and $\mathrm{H}_{2} \mathrm{~S}$ emissions were $49 \pm 6 \%$ and $82 \pm 7 \%$, respectively, over 14 days of measurements. The removal efficiency of $\mathrm{H}_{2} \mathrm{~S}$ was higher than $\mathrm{NH}_{3}$, likely because the $\mathrm{pH}$ of aerobically treated liquid manure remained slightly above 8 . More work is warranted to assess the $\mathrm{N}$ balance in this system and the emissions of odor and greenhouse gasses (GHGs). It is also expected that it will be possible to control the $\mathrm{NH}_{3}$ and $\mathrm{H}_{2} \mathrm{~S}$ removal rates by controlling the nitrification level of the liquid manure in the aerobic treatment system.
\end{abstract}

Keywords: gas emissions; air quality; odor control; livestock production; manure management; Republic of Korea

\section{Introduction}

Gaseous and particulate matter emissions from livestock farming impact the local and regional air quality. However, gaseous emissions composition is very complex. Lo, et al. [1] reported nearly 300 volatile organic compounds (VOCs) emitted from swine manure, with a significant fraction being odorous. Besides VOCs, gaseous emissions from livestock facilities contain gases such as ammonia $\left(\mathrm{NH}_{3}\right)$, hydrogen sulfide $\left(\mathrm{H}_{2} \mathrm{~S}\right)$, and greenhouse gases (GHGs). $\mathrm{NH}_{3}$ is considered an environmental pollutant because when released into the atmosphere, it can cause acid rain and soil acidification [2]. Also, the ammonia present in surface water can cause the eutrophication of rivers [3]. Ammonia can also form secondary fine particulate matter (PM) in the presence of $\mathrm{NO}_{\mathrm{x}}$ or $\mathrm{SO}_{\mathrm{x}}$. The interactions of odorous VOCs with PM are not well understood, but it is evident that PM itself can serve as a carrier of odor and that fine PM can be more odorous [4]. Researchers have discussed potential adverse effects of 
air quality in the context of animal production to health, especially respiratory issues in both workers and animals $[5,6]$. Gaseous emissions can elicit complaints from neighbors $[7,8]$.

Extensive measurements of odorous gas and PM emissions have been conducted to account for a wide range of site-specific conditions such as the animal species, facility size and type, manure management, climate, ventilation schemes, and others [9-14]. It is well known that manure management can have a significant impact on gaseous emissions [15]. Measurements require a major investment of resources and time to account for variability. Still, odor and gaseous measurements are confounded by measurement biases and inconsistencies [13,16-18]. Researchers agree that $\mathrm{NH}_{3}$ and $\mathrm{H}_{2} \mathrm{~S}$ are relatively easy to measure in real time and can (to a limited extent) serve as surrogates for the assessment of odor [19].

Various techniques for reducing odor, gaseous and PM emissions have been developed. Maurer et al. [20] reviewed the effectiveness of technologies for mitigation at the housing, manure storage and treatment and land application scales for swine, poultry, beef cattle, and dairy. The odor reduction techniques for animal housing (barns) can be divided into 'end-of-pipe' and 'source-based' methods [21]. Some of the end-of-pipe techniques include biofilters [22,23], windbreaks, wet scrubbers and ultraviolet light $[24,25]$. The source-based approaches can manage emissions at the odor source, usually addressing emissions from manure. Various topical additives to swine manure surface such as biochar [26], soybean peroxidase [27,28], and poultry manure such as zeolites [29], and bioactive sorbents [30] have been tested. Because swine barn odor is mainly caused by emissions from manure [31], the source-based methods are aimed at proper manure management. Source-based methods comprise feed management, stocking density reduction, and the cooling of manure [21]. Feed management can be expected to reduce $\mathrm{NH}_{3}$ emissions by minimizing $\mathrm{N}$ excretion by controlling the $\mathrm{N}$ content in feed or phase feeding [3,32]. Also, reducing the stocking rate can reduce farm productivity and profitability, and cooling the manure requires a cost. Even with the proper mitigation of gaseous emissions at the source or storage, land application of manure (that is a desired nutrient cycling practice) can also be a source of emissions [33].

The manure pit recharge system could be considered as one of the source-based approaches for manure management. In this method, the pit is periodically recharged with a liquid. Although fresh water can be used as recharge liquid [34], recycled effluent from an anaerobic lagoon is more practical [35,36]. It is known as a manure collection system and is also reported to be an effective method to prevent the volatilization of odorous substances by diluting the swine manure. Kai et al. [34] reported the $\mathrm{NH}_{3}$ emission reduction rate for a pit recharge system with fresh water ranging between 54 and $88 \%$ when compared with previously reported gas emission from conventional manure collection systems. Similarly Lim et al. [35] reported the reduction rates of $\mathrm{NH}_{3}$ and $\mathrm{H}_{2} \mathrm{~S}$ were $52-63 \%$ and $17-41 \%$, respectively when recharging frequencies ranged from 7 to 14 days with lagoon effluent. In addition, Blunden et al. [36] reported emission rates for $\mathrm{NH}_{3}$ and $\mathrm{H}_{2} \mathrm{~S}$, and $\mathrm{Ha}$ and Kim [37] reported $\mathrm{NH}_{3}$ and $\mathrm{H}_{2} \mathrm{~S}$ concentrations inside the swine barn equipped with a pit recharge system without explicitly reporting the reduction of gaseous emissions. The summary of the literature on the performance of pit recharge systems is shown in Table 1.

To date, the pit recharge system described in literature used either water [34] or treated manure $[35,36]$ where the entire shallow manure pit is drained (a batch mode) and recharged with a treated lagoon effluent. The use of water can be problematic as it is an expensive resource in some livestock production areas, and it can also increase the volume of manure. The batch recharge, while feasible, adds to the personnel management workload and the need for additional scheduled monitoring and operation (sometimes not feasible in highly automated production systems). 
Table 1. Summary of $\mathrm{NH}_{3}, \mathrm{H}_{2} \mathrm{~S}$ and odor emission from swine barns equipped with a batch-mode pit recharge system reported in previous studies.

\begin{tabular}{|c|c|c|c|c|c|c|c|c|}
\hline Study & $\begin{array}{l}\text { Experimental Scale } \\
\text { \& Location }\end{array}$ & $\begin{array}{l}\text { Growth Stage } \\
\quad \& \text { Size }\end{array}$ & $\begin{array}{c}\text { Description of } \\
\text { Barn }\end{array}$ & $\begin{array}{c}\text { Recharged } \\
\text { Liquid \& Volume }\end{array}$ & $\begin{array}{l}\text { Recharging } \\
\text { Frequency }\end{array}$ & $\begin{array}{l}\text { Experimental } \\
\text { Period and } \\
\text { Season }\end{array}$ & $\begin{array}{c}\text { Gas \& Odor; } \\
\text { Emission Rate } \\
\left(\mathrm{g} \mathrm{d}^{-1} \mathrm{AU}^{-1}\right)^{1} \\
\end{array}$ & $\begin{array}{c}\text { Measured Gas } \\
\text { Emissions } \\
\text { Reduction Rate (\%) }\end{array}$ \\
\hline \multirow{3}{*}{$\begin{array}{l}\text { Lim et al. (2004) } \\
\text { [35] }\end{array}$} & \multirow{3}{*}{$\begin{array}{l}\text { Research barn } \\
\text { Indiana, US }\end{array}$} & \multirow{3}{*}{$\begin{array}{l}78-97 \mathrm{~kg} \\
\text { finisher, } \\
75 \text { pigs }\end{array}$} & \multirow{3}{*}{$\begin{array}{l}\text { Shallow pit } \\
\text { (1.1 m deep), } \\
\text { Fully slatted }\end{array}$} & \multirow{3}{*}{$\begin{array}{l}\text { Anaerobic treated } \\
\text { lagoon effluent, } \\
72 \mathrm{~L} \mathrm{head}^{-1}\end{array}$} & $\begin{array}{c}1 \text { wk, } \\
\text { Batch mode }\end{array}$ & $\begin{array}{l}\text { May-July } \\
(3 \mathrm{wks})\end{array}$ & $\begin{array}{c}\mathrm{NH}_{3} ; 10 \\
\mathrm{H}_{2} \mathrm{~S} ; 0.16 \\
\text { Odor; } 2.6 \mathrm{OU}_{\mathrm{E}} \mathrm{s}^{-1}\end{array}$ & $\begin{array}{l}63 \\
41\end{array}$ \\
\hline & & & & & $\begin{array}{c}2 \text { wks, } \\
\text { Batch mode }\end{array}$ & $\begin{array}{l}\text { May-July } \\
(6 \mathrm{wks})\end{array}$ & $\begin{array}{c}\mathrm{NH}_{3} ; 12 \\
\mathrm{H}_{2} \mathrm{~S} ; 0.34\end{array}$ & $\begin{array}{l}52 \\
17\end{array}$ \\
\hline & & & & & $\begin{array}{c}6 \mathrm{wks} \\
\text { Batch mode }\end{array}$ & $\begin{array}{l}\text { March-May } \\
\quad(7 \mathrm{wks})\end{array}$ & $\begin{array}{c}\mathrm{NH}_{3} ; 11 \\
\mathrm{H}_{2} \mathrm{~S} ; 1.42 \\
\text { Odor; } 25 \mathrm{OU}_{\mathrm{E}} \mathrm{s}^{-1}\end{array}$ & Not reported ${ }^{2}$ \\
\hline $\begin{array}{c}\text { Kai et al. (2006) } \\
\text { [34] }\end{array}$ & $\begin{array}{l}\text { Research barn } \\
\text { Denmark }\end{array}$ & $\begin{array}{c}25-45 \mathrm{~kg} \text { grower } \\
20 \text { pigs }\end{array}$ & $\begin{array}{l}\text { Shallow pit } \\
(0.3 \mathrm{~m} \text { deep), } \\
\text { Fully slatted } \\
\end{array}$ & $\begin{array}{l}\text { Fresh water, } \\
6 \mathrm{~L} \mathrm{head}^{-1}\end{array}$ & $\begin{array}{c}1 \mathrm{wk} \\
\text { Batch mode }\end{array}$ & $1 \mathrm{wk}$ & $\begin{array}{c}\mathrm{NH}_{3} ; 17-23 \\
\text { Odor; } 6.0 \mathrm{OU} \mathrm{s}^{-1}\end{array}$ & Not reported \\
\hline \multirow{3}{*}{$\begin{array}{l}\text { Blunden et al. } \\
\text { (2008) [36] }\end{array}$} & \multirow{3}{*}{$\begin{array}{l}\text { Commercial barn } \\
\text { North Carolina, US }\end{array}$} & \multirow{3}{*}{$\begin{array}{l}\text { 38-88 kg } \\
\text { finisher } \\
\text { 842-896 pigs }\end{array}$} & \multirow{3}{*}{$\begin{array}{l}\text { Shallow pit, } \\
\text { Fully slatted }\end{array}$} & \multirow{3}{*}{$\begin{array}{l}\text { Anaerobic treated } \\
\text { Lagoon fluid } \\
\text { (No information } \\
\text { about volume) }\end{array}$} & \multirow{3}{*}{$\begin{array}{c}1 \text { wk, } \\
\text { Batch mode }\end{array}$} & $\begin{array}{c}\text { February } \\
\text { (6 days) }\end{array}$ & $\mathrm{NH}_{3} ; 40.8, \mathrm{H}_{2} \mathrm{~S} ; 4.2$ & \multirow{3}{*}{ Not reported } \\
\hline & & & & & & April (8 days) & $\mathrm{NH}_{3} ; 37.1, \mathrm{H}_{2} \mathrm{~S} ; 3.3$ & \\
\hline & & & & & & June (6 days) & $\mathrm{NH}_{3} ; 29.5, \mathrm{H}_{2} \mathrm{~S} ; 1.2$ & \\
\hline $\begin{array}{l}\text { Ha and Kim } \\
(2015)^{3}[37]\end{array}$ & $\begin{array}{l}\text { Commercial barn } \\
\text { Republic of Korea }\end{array}$ & Not reported & Not reported & $\begin{array}{l}\text { Aerobically } \\
\text { treated liquid } \\
\text { manure }\end{array}$ & Not reported & Not reported & Not reported & Not reported \\
\hline
\end{tabular}

${ }^{1} 500 \mathrm{~kg}$ of live animal weight; ${ }^{2}$ Only absolute emissions are reported; ${ }^{3} \mathrm{Ha}$ and $\mathrm{Kim}(2015)$ measured concentration of $\mathrm{NH}_{3}$ and $\mathrm{H}_{2} \mathrm{~S}$, not emission rates 
Thus, approximately 100 swine farmers in the Republic of Korea have adopted a more frequent semi-continuous pit recharge system. Recharging manure is diverted daily from the aerobic treatment of swine manure that is part of a comprehensive manure treatment that aims at reducing odorous emissions while generating high-quality liquid fertilizers. Still, very little is known about the actual performance of this kind of highly-integrated pit recharge system on $\mathrm{NH}_{3}$ and $\mathrm{H}_{2} \mathrm{~S}$ emissions from a swine barn. Ha and Kim [37] measured gas concentrations from a barn with conventional slurry pit and three barns equipped with a pit recharge system. Reduction of $\mathrm{NH}_{3}$ and $\mathrm{H}_{2} \mathrm{~S}$ concentrations were reported as $35-84 \%$ and $0-100 \%$, respectively, but emission rates have not been reported.

In this research, for the first time, we tested the performance of the semi-continuous pit recharge system on mitigation of $\mathrm{NH}_{3}$ and $\mathrm{H}_{2} \mathrm{~S}$ emissions from a swine finisher barn in Korea. The pit recharge system using aerobically treated liquid manure (treated manure diverted back into the pit) has been developed for gaseous emissions reduction method for swine barn (Figure 1). This method (of daily removal of manure) can improve the air quality inside a barn by reducing odorous gas generation [38]. Therefore, the number of farms using a pit recharge system has been steadily increasing in the Republic of Korea, but no studies reported the efficiency of $\mathrm{NH}_{3}$ and $\mathrm{H}_{2} \mathrm{~S}$ emission reduction from swine barns equipped with a pit recharge system with aerobically treated manure.

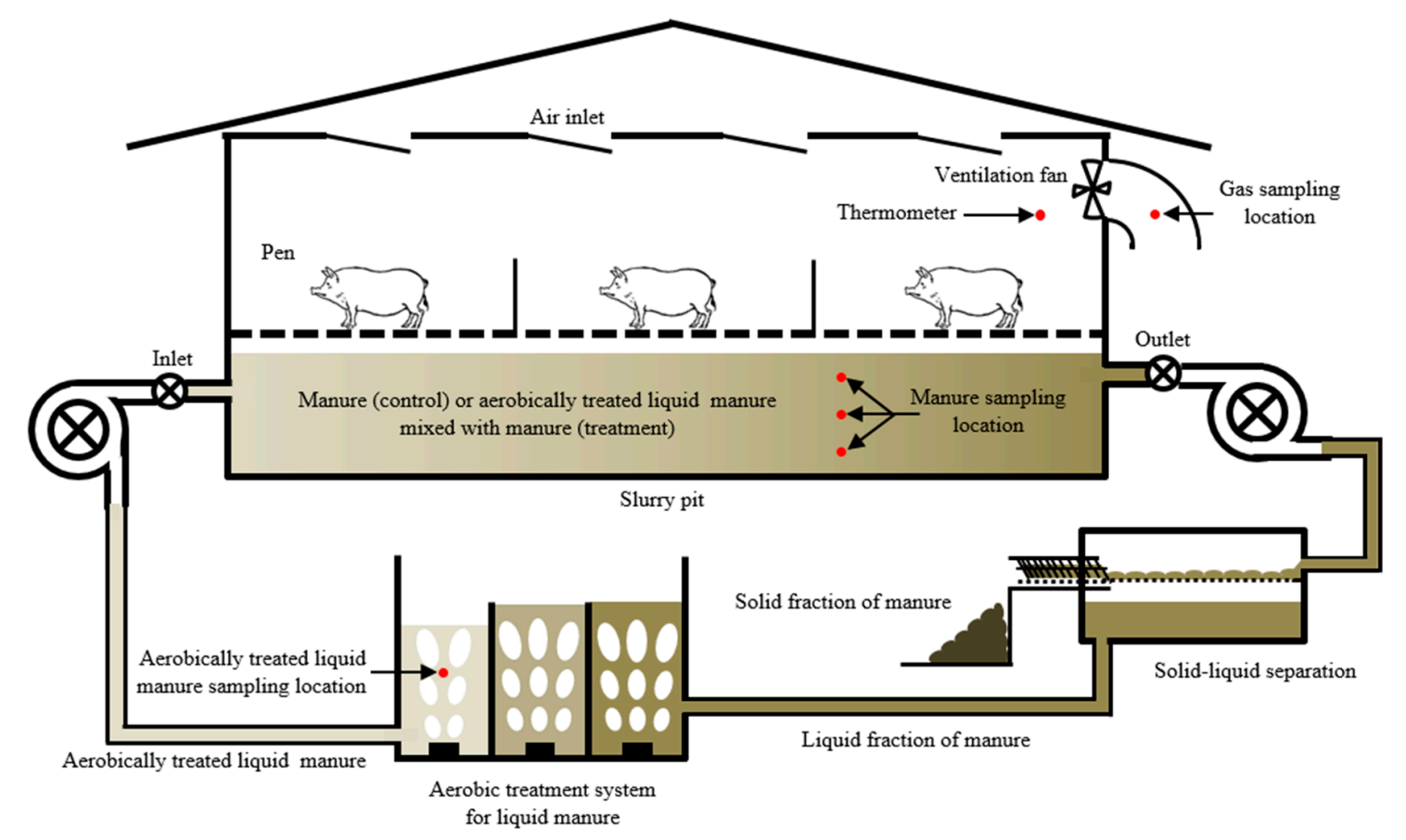

Figure 1. Pit recharge system with aerobically treated liquid manure. After solids separation, the liquid fraction goes to the sequential aerobic treatment system, which can be considered as equivalent to autothermal thermophilic aerobic digestion (ATAD) in Europe [39]. The aerobically treated liquid manure is used as the recharging liquid of the pit recharge system.

The main objective of this study was to evaluate the performance of a pit recharge system on $\mathrm{NH}_{3}$ and $\mathrm{H}_{2} \mathrm{~S}$ emissions from a swine finishing barn for a typical farm operation in the Republic of Korea. Specifically, we compared $\mathrm{NH}_{3}$ and $\mathrm{H}_{2} \mathrm{~S}$ emissions between conventional a slurry pit and a pit recharged with aerobically treated manure.

\section{Experiments}

\subsection{Description of Farm and Design of Experiment}

The experimental site was a commercial pork production farm, located in Buyeo, Chungnam Province in the Republic of Korea. The experiment was carried out for two weeks from 30 September 
to 13 October 2017. During this period, the average temperature outside the barn was $17.3 \pm 2.9^{\circ} \mathrm{C}$. Two identical swine rooms (with and without a pit recharge system) in one confinement building for finishing pigs were used to evaluate the effect of a pit recharge system to gas emission rates (Figure 1, Figure A1). Each tested room was representative of a total of three rooms operating in the same mode. A room with conventional slurry pit was used as a control and the other one was pit recharged with a total $12 \mathrm{~m}^{3}$ (approximately 10 times the daily production of manure from 240 pigs; designed based on the assumption of $5.1 \mathrm{~kg}$ of combined manure and waste water produced daily per head) of aerobically treated liquid manure three times (6 A.M., 12 P.M., 6 P.M.) daily. The total amount of recharged aerobically treated liquid manure in a day was about $7.3 \%$ of the total stored manure in the pit. Manure and recharged liquid was filled to about $70 \%$ of the total pit volume and kept at a constant depth $(82 \mathrm{~cm})$ throughout the experiment period. The manure from rooms 5, 6 and 7 (Figure A1) was treated collectively, i.e., each room was pumped out automatically on a round-robin basis. Thus, the recharging liquid from the aeration system was a mixture of treated manure from three pits (rooms 5 to 7). Manure from the conventional slurry pit is pumped out every 2-3 months and transported to a centralized manure treatment plant. The manure in the slurry pit was totally emptied when the pigs were introduced into the control room first, then the amount of manure slowly increased while the pigs growing. The manure volume of control room was about $70 \%$ of total pit volume (79 $\mathrm{cm}$ depth at day 13), almost the same depth to the pit recharged room, when the gas emissions were monitored (Figure A2). The treated liquid manure from pit recharge system is considered as a "liquid fertilizer" and is periodically pumped out to a large on-farm storage tank, and then land applied during the growing season (e.g., 1-3 times per year for rice). Each room had 240 pigs weighing approximately $80 \mathrm{~kg}$, fed with feed containing $17.5 \%$ crude protein (Table 2). The stocking density was $0.79 \mathrm{~m}^{2}$ head $^{-1}$. The rooms had a fully-slatted floor. Manure pits (1.2 $\mathrm{m}$ deep in each room) were separated and managed independently in the conventional storage system (Figure A2). Fixed walls separated pits under each room, i.e., there was no air exchange between rooms or pit headspaces. Air ventilation system was separated in each room and managed independently. The eight air inlets (one-side baffle type, $300 \times 300 \mathrm{~mm}$ ) were in the ceiling, and three exhaust ventilation fans were wall-mounted (Figure A3). One primary ventilation fan $(\Phi 550 \mathrm{~mm})$ operated continuously at a constant rate $\left(88 \mathrm{~m}^{3} \mathrm{~min}^{-1}\right)$, and the others $(\Phi 1000 \mathrm{~mm})$ operated with variable speed, $110 \sim 210 \mathrm{~m}^{3} \mathrm{~min}^{-1}$, to maintain set point room temperature $\left(25^{\circ} \mathrm{C}\right)$. The operation of both fans is mostly in the summer season, and during the whole experimental periods for this study, only one of $\Phi 1000 \mathrm{~mm}$ fans had operated. The gas sampling location of each room was immediately downstream of each continuously operated fan.

Table 2. Characteristics of feed used in this study.

\begin{tabular}{cc}
\hline Item & Contents (\%, d.b. $\left.{ }^{\mathbf{1}}\right)$ \\
\hline Crude protein & 17.48 \\
Crude fiber & 5.16 \\
Fat & 2.91 \\
\hline \multicolumn{2}{c}{}
\end{tabular}

\subsection{Ammonia and Hydrogen Sulfide}

The real-time monitoring system (OMS-200, Smart Control \& Sensing Inc., Daejeon, Rep. of Korea; Figure A1) equipped with electrochemical gas sensors of Membrapor Co. (Wallisellen, Switzerland) were used to measure $\mathrm{NH}_{3}(\mathrm{NH} 3 / \mathrm{CR}-50)$ and $\mathrm{H}_{2} \mathrm{~S}(\mathrm{H} 2 \mathrm{~S} / \mathrm{C}-50)$ concentrations. Both gas sensors were calibrated with standard gases on the day before the start of the experiment. The detailed performance data of both sensors are shown in Table A1. The real-time monitoring system sampled room air

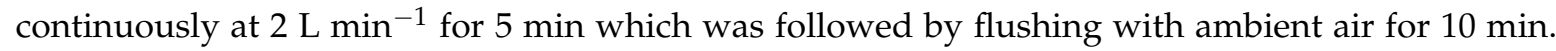
This was done to minimize the risk of sensor overload and signal drift. 
Airflow measurement assembly (AMA, MJ Tech., Seoul, Rep. of Korea) was installed in each exhaust fan (Figure A1) and calibrated with hot wire anemometers at varying ventilation stages. The calibrated AMA provided a real-time ventilation rate to the OMS-200. The status of ventilation fan operation was monitored using AC-to-DC power supply adapters which provide fan power voltages and on/off signals to the monitoring system. Room temperature was measured with thermometer with integral PTAT (proportional to absolute temperature) silicon transistor (Econarae, MHTP-485S). Finally, the $\mathrm{NH}_{3}$ and $\mathrm{H}_{2} \mathrm{~S}$ emissions from each tested swine room were estimated with the following equation:

$$
\begin{aligned}
& \text { Gas emission per hour }\left(\mathrm{g} \mathrm{h}^{-1} \text { head }^{-1}\right)=\left(C_{E} \times \mathrm{V} \times \frac{273.15 \times \mathrm{MW}}{\left(273.15+T_{E}\right) \times 22.4 \times 10^{3}}-\right. \\
& \left.\qquad C_{A} \times \mathrm{V} \times \frac{273.15 \times \mathrm{MW}}{\left(273.15+T_{A}\right) \times 22.4 \times 10^{3}}\right) \times 60 \div \text { heads }
\end{aligned}
$$

$C_{E}=$ Gas concentration of exhausted air $\left(\mathrm{mL} \mathrm{m}^{-3}\right)$

$\mathrm{V}=$ Room ventilation rate $\left(\mathrm{m}^{3} \mathrm{~min}^{-1}\right)$

$\mathrm{MW}=$ Molecular weight of target gas $\left(\mathrm{g} \mathrm{mol}^{-1}\right)$

$\mathrm{T}_{\mathrm{E}}=$ Exhaust air temperature $\left({ }^{\circ} \mathrm{C}\right)$

$\mathrm{C}_{\mathrm{A}}=$ Gas concentration of ambient air $\left(\mathrm{mL} \mathrm{m}^{-3}\right)$

$\mathrm{T}_{\mathrm{A}}=$ Ambient air temperature $\left({ }^{\circ} \mathrm{C}\right)$

\subsection{Manure Analysis}

The recharging manure (aerobically treated) was sampled at the first (day 0) and final (day 13) days of the experiment (Figure 1), and recharged liquid mixed with manure was collected from the slurry pit under swine room once (day 13) (Figure A3). Manure from the conventional slurry pit (control) was sampled on day 13 (Figure A3). Samples from each pit were collected at three different heights of $60 \mathrm{~cm}$ (shallow), $40 \mathrm{~cm}$ (middle), and $20 \mathrm{~cm}$ (deep) from the bottom of the pit (Figure A2). Manure samples were stored below $4{ }^{\circ} \mathrm{C}$ and analyzed for total solids (TS), volatile solids (VS), $\mathrm{pH}$, electric conductivity (EC), total nitrogen (TN), and ammonium nitrogen $\left(\mathrm{NH}_{4}-\mathrm{N}\right)$. TS and VS were analyzed with the standard American Public Health Association (APHA) methods. The $\mathrm{pH}$ and EC measurements were conducted using a digital $\mathrm{pH}$ meter with a combination glass electrode (Thermo Scientific, Orion 4 Star $\mathrm{pH}$, and EC conductivity benchtop meter). The TN content in manure was measured using the modified Gunning method (utilizing sulfuric-salicylic acid mixture, a.k.a. total Kjeldahl nitrogen). To detect $\mathrm{NH}_{4}-\mathrm{N}$ in manure, the photometric analysis was used (Thermo Scientific, Gallery Discrete Analyzer).

\subsection{Statistical Analysis}

We analyzed the Durbin-Watson value of each dataset with SPSS Statistics (IBM Corp., version 24) and judged whether the data were suitable for the $T$-test. The prescreened data were then evaluated with Origin Pro software (Origin Lab, version 9) for statistical significance using two-sample $T$-test. A significant difference between control and treatment was determined at a significance level of $p<0.05$.

\section{Results}

\subsection{Ammonia Emissions of Each Room}

Figure 2a illustrates the measured $\mathrm{NH}_{3}$ concentrations at each primary fan in control (conventional slurry pit) and treatment (pit recharge system) room during the entire experimental period. In both swine room, $\mathrm{NH}_{3}$ concentration decreased through whole periods, and within treatment, the fluctuations of concentration had a distinct diurnal pattern. The ranges of $\mathrm{NH}_{3}$ concentrations in control and treatment were 7.3-35.5 ppmv and 3.7-25.0 ppmv, respectively. 


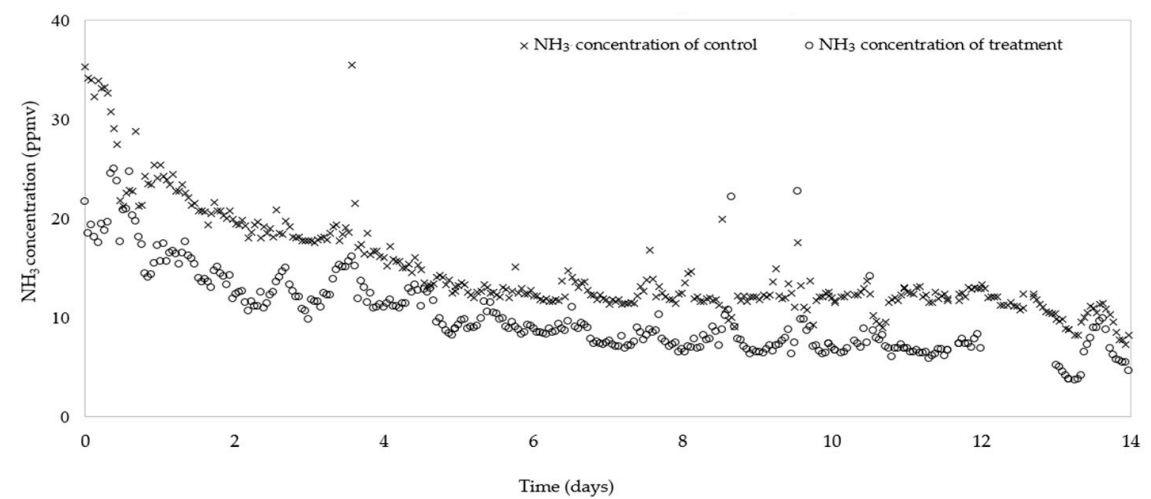

(a)

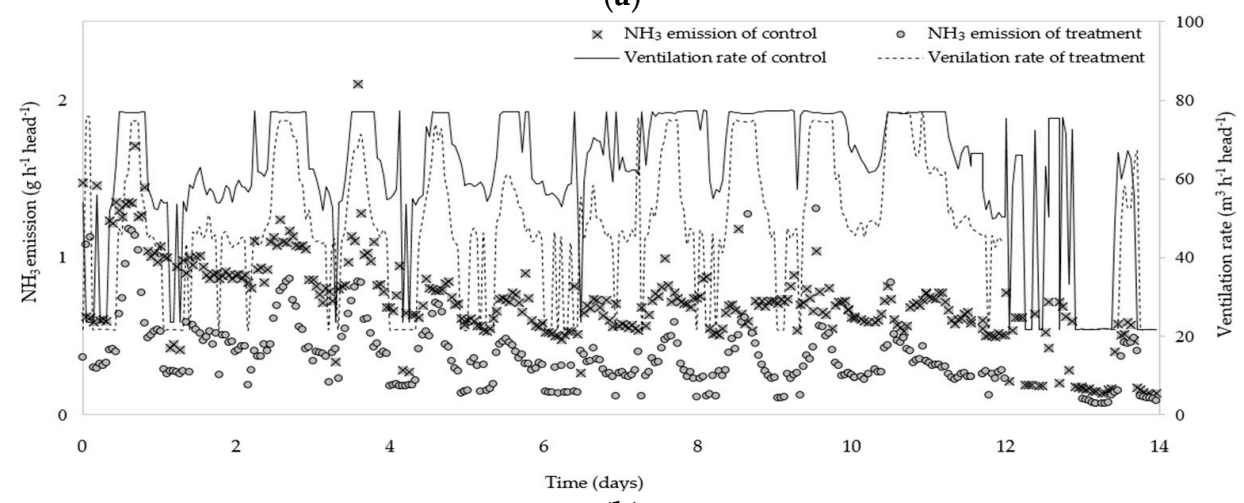

(b)

Figure 2. Comparison of measured $\mathrm{NH}_{3}$ concentrations and emissions from control (conventional slurry pit) and treatment (pit recharge system). (a) Measured concentration; (b) estimated emission and ventilation rates.

The ranges of ventilation rate of both rooms were $22-77 \mathrm{~m}^{3} \mathrm{~h}^{-1}$ head ${ }^{-1}$. Due to the primary fan operating with constant rates $\left(88 \mathrm{~m}^{3} \mathrm{~min}^{-1}\right)$, and the secondary fan operating at $110-210 \mathrm{~m}^{3} \mathrm{~min}^{-1}$, there was a gap between $22 \mathrm{~m}^{3}$ head ${ }^{-1} \mathrm{~h}^{-1}$ to about $45 \mathrm{~m}^{3}$ head ${ }^{-1} \mathrm{~h}^{-1}$ (Figure 3). The ranges of $\mathrm{NH}_{3}$ emission rate were $0.1-2.1,0.1-1.3 \mathrm{~g} \mathrm{~h}^{-1}$ head $^{-1}$ in the and treatment, respectively. The hourly $\mathrm{NH}_{3}$ emission rates showed a correlation with the ventilation rates of both rooms (Figure $2 \mathrm{~b}$ ). Correlation coefficients were calculated to examine the relationships between ventilation rates and $\mathrm{NH}_{3}$ concentrations and emissions. The correlation coefficients of ventilation rate and $\mathrm{NH}_{3}$ emission were 0.61 and 0.69 in control and treatment, respectively (Figure 3). On the other hand, there was no apparent correlation between $\mathrm{NH}_{3}$ concentration and ventilation rate in both rooms, i.e., the coefficients of control and treatment were $-0.06,0.07$, respectively.

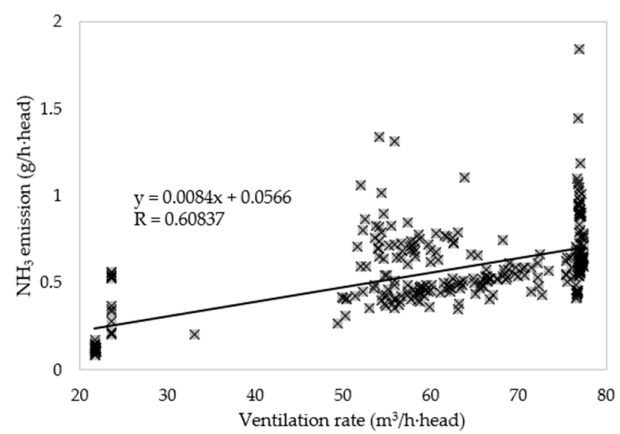

(a)

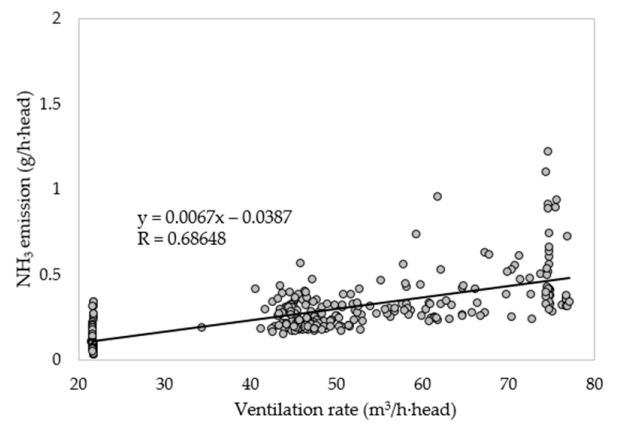

(b)

Figure 3. Correlation between ventilation rate and $\mathrm{NH}_{3}$ emission in control (conventional slurry pit) and treatment (pit recharge system). (a) The correlation coefficient of ventilation rate and $\mathrm{NH}_{3}$ emission in control (conventional slurry pit) was 0.61 , (b) 0.69 in treatment (pit recharge system). 
Figure 4 shows the typical diurnal variations of $\mathrm{NH}_{3}$ concentrations and emissions, outside and inside temperatures, ventilation rates of control and treatment (shown for day 5 of the experiment). The room temperature was tightly controlled at around $25{ }^{\circ} \mathrm{C}$, which was the desired set point. To maintain this set point, the ventilation rate in daytime increased with the increasing the temperature outside. The $\mathrm{NH}_{3}$ concentrations were stable and ranged from 12-15 ppmv and from 8-12 ppmv at control and treatment, respectively. However, the $\mathrm{NH}_{3}$ emissions reflected the diurnal ventilation rate pattern.

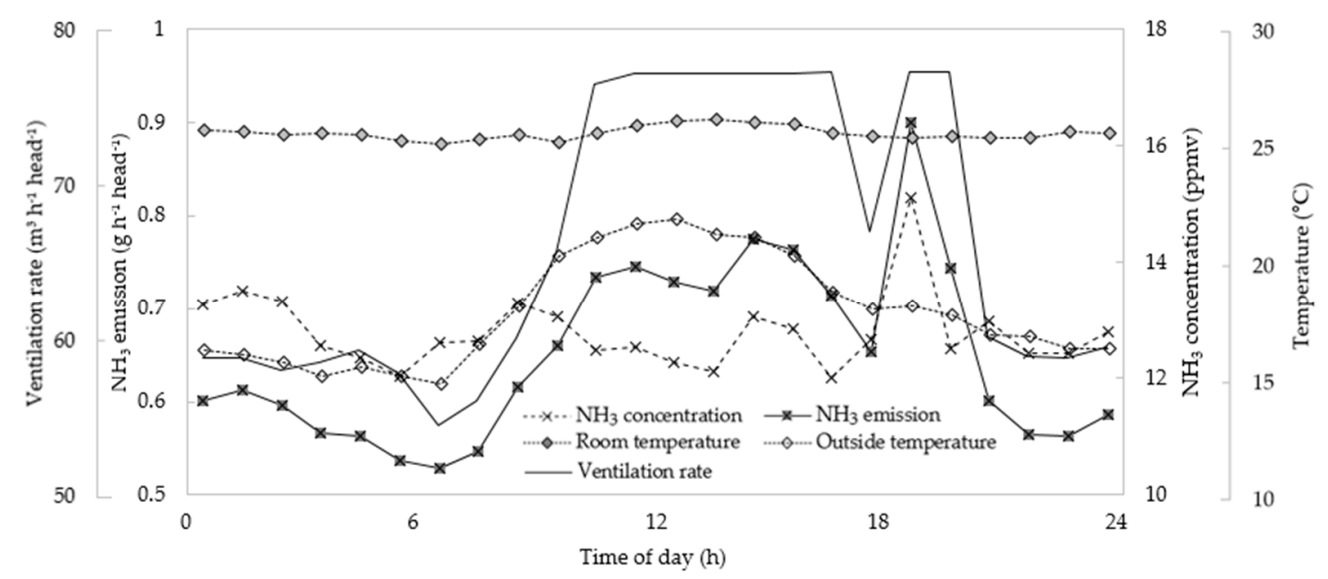

(a)

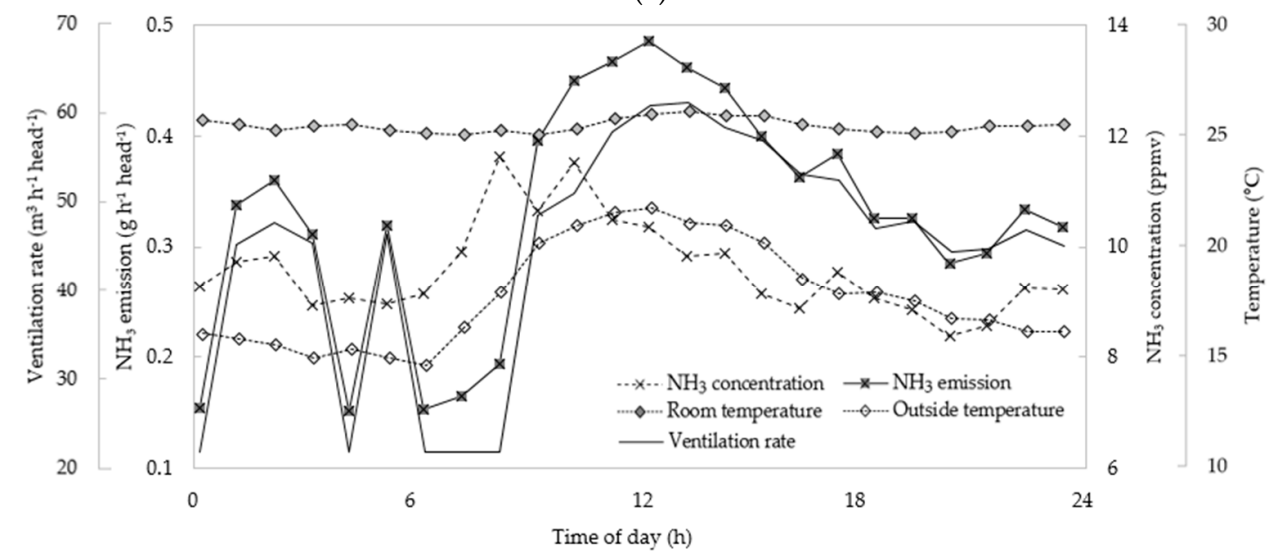

(b)

Figure 4. Diurnal variations of temperature, ventilation rate and generated $\mathrm{NH}_{3}$ from (a) control (conventional slurry pit) room, (b) treatment (pit recharge system) room on day 5.

\subsection{Hydrogen Sulfide Emissions}

The real-time measured $\mathrm{H}_{2} \mathrm{~S}$ concentrations and estimated emissions are shown in Figure 5. The large difference in $\mathrm{H}_{2} \mathrm{~S}$ concentrations was observed between the control (conventional slurry pit) and treatment (pit recharge system) room. The range of $\mathrm{H}_{2} \mathrm{~S}$ concentration in control was 488-2310 ppbv, while 84-1378 ppbv measured in treatment. From day 12 of the experiment, $\mathrm{H}_{2} \mathrm{~S}$ concentration in control increased because the ventilation rate decreased to maintain room temperature. As with $\mathrm{NH}_{3}$, the emissions of $\mathrm{H}_{2} \mathrm{~S}$ reflected the ventilation rates of each room.

Figure 6 presents the $\mathrm{H}_{2} \mathrm{~S}$ concentration plotted against the ventilation rate in control and treatment rooms. At the control, $\mathrm{H}_{2} \mathrm{~S}$ concentration and ventilation rates were negatively correlated, the coefficient was -0.58 . It is likely caused by a dilution effect due to the increased ventilation rate. In the treatment, the correlation between $\mathrm{H}_{2} \mathrm{~S}$ concentration and ventilation rate was poor $(\mathrm{R}=0.01)$. 


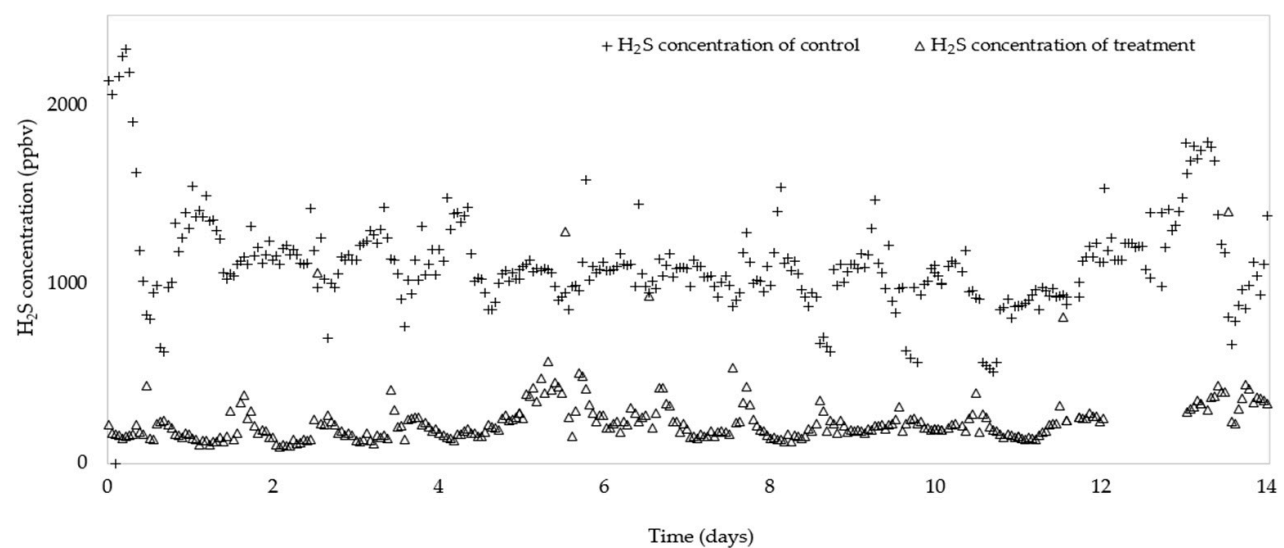

(a)

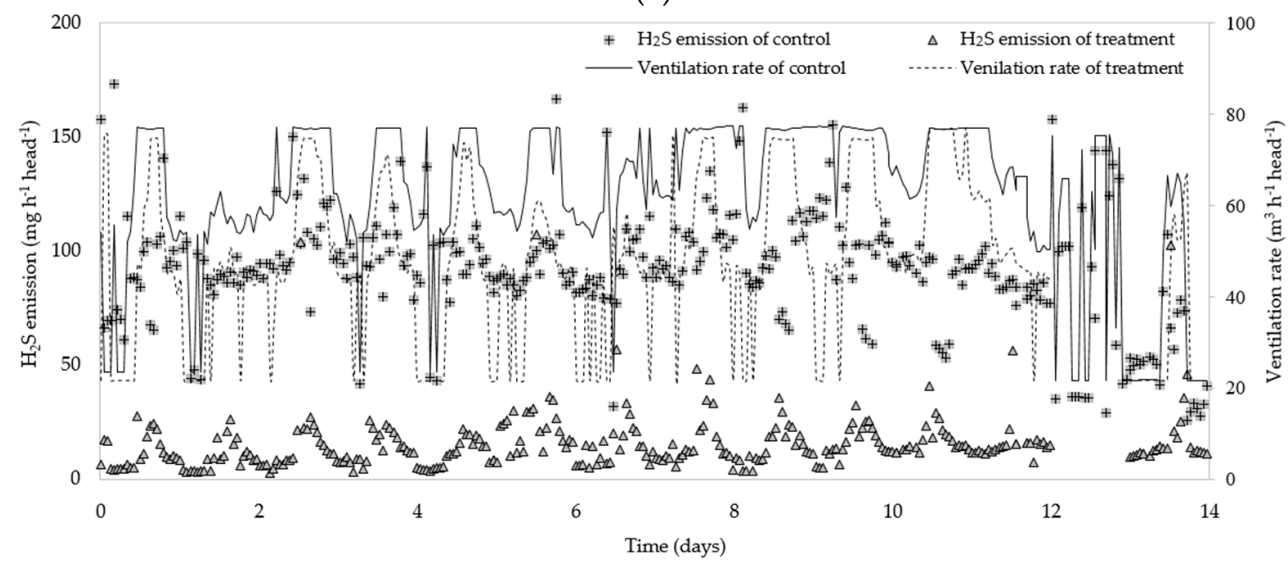

(b)

Figure 5. Comparison of measured $\mathrm{H}_{2} \mathrm{~S}$ concentrations and emissions from control (conventional slurry pit) and treatment (pit recharge system). (a) Measured concentration (ppmv); (b) estimated emission and ventilation rate.

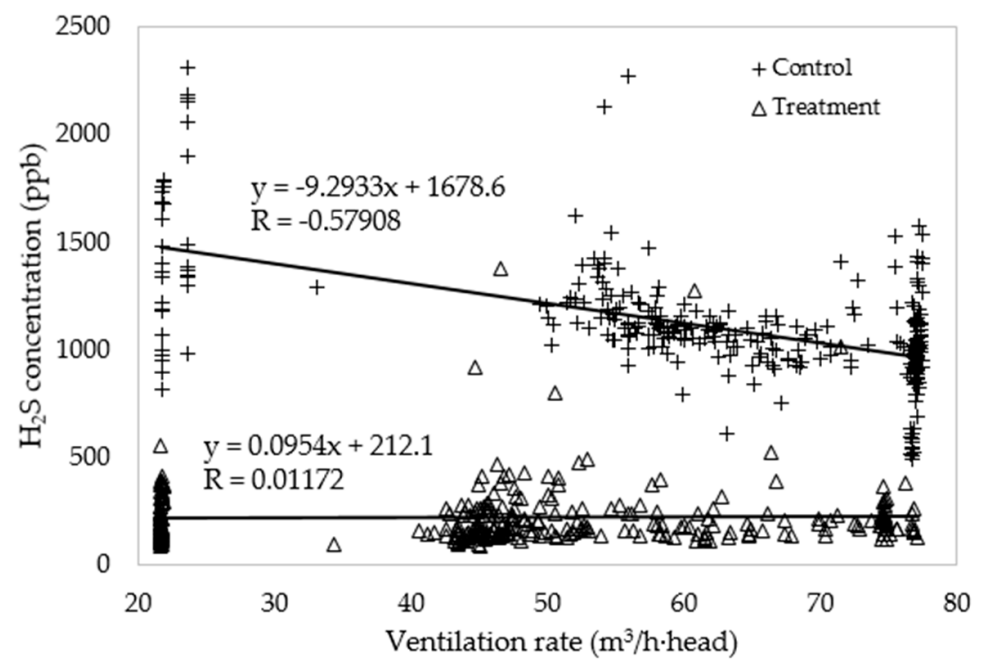

Figure 6. Correlation between ventilation rate and $\mathrm{H}_{2} \mathrm{~S}$ concentration in control (conventional slurry pit) and treatment (pit recharge system).

The $\mathrm{H}_{2} \mathrm{~S}$ emissions and ventilation rates indicate correlation in both rooms where the correlation coefficients were $0.69,0.44$ in the control and treatment, respectively (Figure 7). 


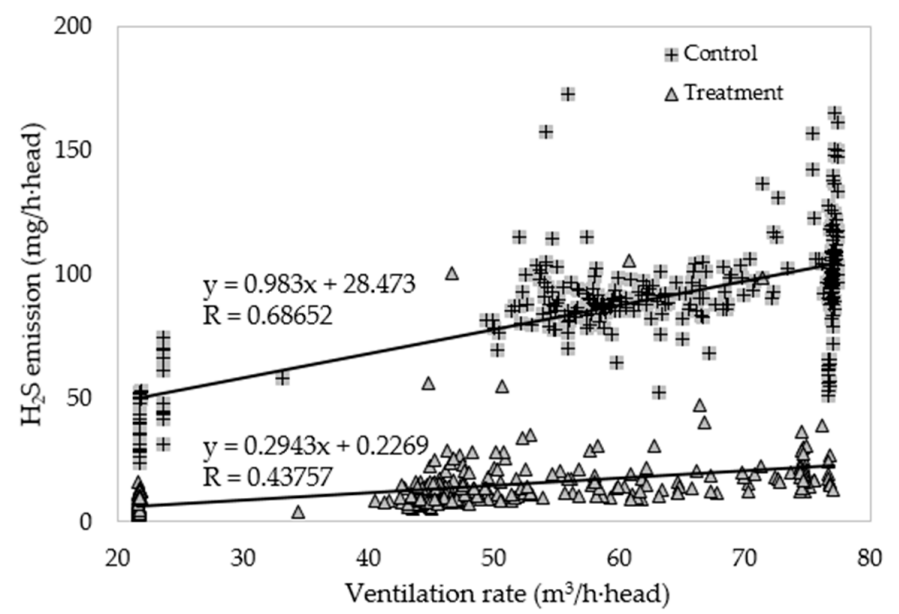

Figure 7. Correlation between ventilation rate and $\mathrm{H}_{2} \mathrm{~S}$ emission in control (conventional slurry pit) and treatment (pit recharge system).

Figure 8 shows typical diurnal variations of $\mathrm{H}_{2} \mathrm{~S}$ concentration and emission, outside and inside temperature, a ventilation rate of control and treatment (shown for day 5 of the experiment). In control (Figure 8a), the $\mathrm{H}_{2} \mathrm{~S}$ concentration peaked at around 18:00, and the $\mathrm{NH}_{3}$ concentration was also peaked at the same time (Figure 4a). This is presumably due to random operations on the farm; i.e., workers needed to enter rooms for maintenance, surveys, repairs of feed bin, at that time. In treatment, the $\mathrm{H}_{2} \mathrm{~S}$ concentration and emission during a day seemed to be less affected by the variation of temperature and ventilation rates, and the highest concentration was measured around noon.

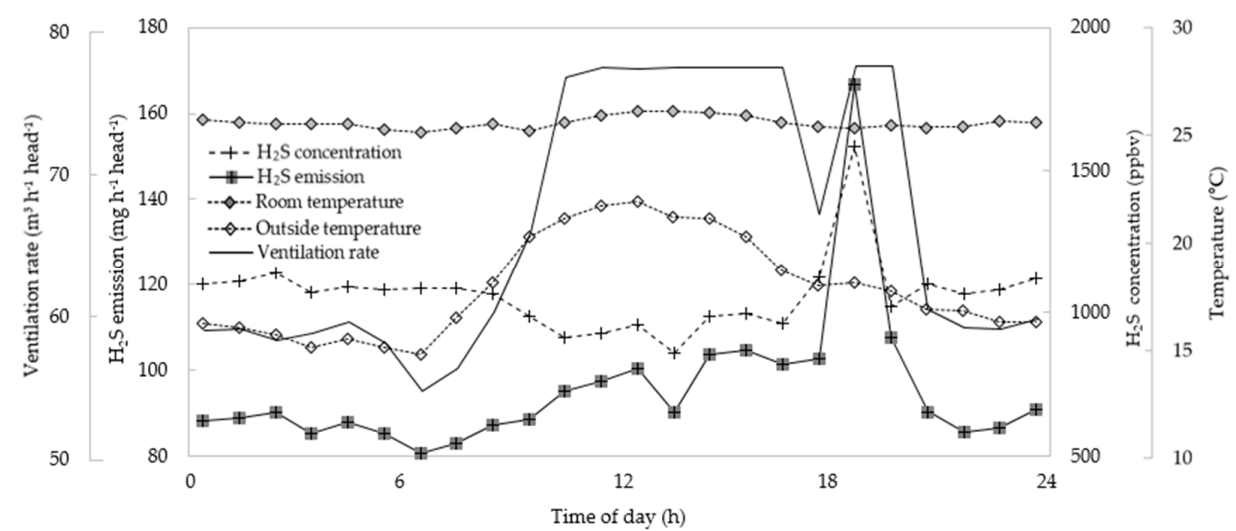

(a)

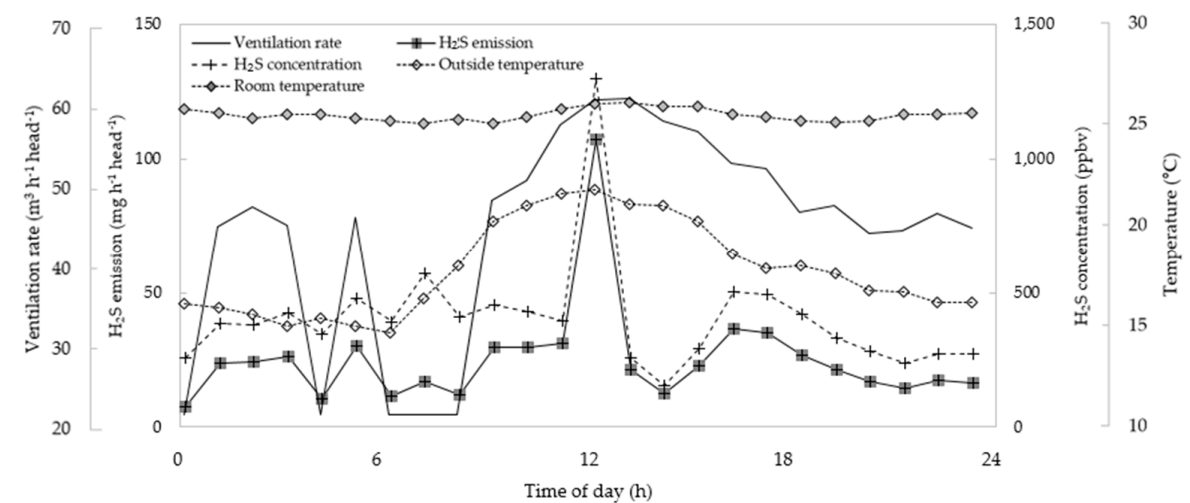

(b)

Figure 8. Diurnal variations of temperature, ventilation rate and generated $\mathrm{H}_{2} \mathrm{~S}$ from (a) control (conventional slurry pit) room, (b) treatment (pit recharge system) room on day 5. 


\subsection{Gas Reduction Rates}

The averages of daily mean $\mathrm{NH}_{3}, \mathrm{H}_{2} \mathrm{~S}$ concentrations and emissions are shown in Table 3. The average of each room temperature was about $25{ }^{\circ} \mathrm{C}$, i.e., no statistical difference in control and treatment $(p>0.05)$. The reduction of gas concentrations was $37.1 \%$ and $79.8 \%$ for $\mathrm{NH}_{3}$ and $\mathrm{H}_{2} \mathrm{~S}$, respectively, for the room equipped with the pit recharge system. Reduction rates of emission were significant $(p<0.0000)$, i.e., $53.3 \%$ and $83.7 \%$ for $\mathrm{NH}_{3}$ and $\mathrm{H}_{2} \mathrm{~S}$, respectively.

Table 3. Average of daily mean $\mathrm{NH}_{3}$ and $\mathrm{H}_{2} \mathrm{~S}$ concentrations and emission rates in control (conventional slurry pit) and treatment (pit recharge system).

\begin{tabular}{|c|c|c|c|c|}
\hline & Control & Treatment & $p$-Value & Reduction Rate (\%) \\
\hline$n$ & 14 & 13 & - & \\
\hline Room temperature $\left({ }^{\circ} \mathrm{C}\right)$ & $25.0 \pm 0.7^{\mathrm{a}}$ & $25.1 \pm 0.6^{\mathrm{a}}$ & 0.7125 & - \\
\hline Ventilation rate $\left(\mathrm{m}^{3} \mathrm{~h}^{-1}\right.$ head $\left.^{-1}\right)$ & $62.0 \pm 11.7$ & $47.0 \pm 9.0$ & - & - \\
\hline \multicolumn{5}{|l|}{ Gas concentration } \\
\hline $\mathrm{NH}_{3}(\mathrm{ppmv})$ & $14.9 \pm 5.0$ & $10.3 \pm 3.8$ & - & $32.6 \pm 5.3$ \\
\hline $\mathrm{H}_{2} \mathrm{~S}(\mathrm{ppbv})$ & $1,122 \pm 137$ & $239 \pm 75$ & - & $78.3 \pm 6.8$ \\
\hline \multicolumn{5}{|l|}{ Gas emission rate } \\
\hline $\mathrm{NH}_{3}\left(\mathrm{~g} \mathrm{~d}^{-1}\right.$ head $\left.^{-1}\right)$ & $13.8 \pm 4.5^{\mathrm{a}}$ & $6.6 \pm 2.4^{b}$ & 0.0000 & $53.3 \pm 6.6$ \\
\hline $\mathrm{H}_{2} \mathrm{~S}\left(\mathrm{mg} \mathrm{d}^{-1}\right.$ head $\left.^{-1}\right)$ & $2,146 \pm 311^{a}$ & $338 \pm 92^{b}$ & 0.0000 & $83.7 \pm 6.8$ \\
\hline
\end{tabular}

a,b Different superscripts in the same row meaning each group are significantly different $(p<0.05)$.

Due to the difference between average ventilation rates of control and treatment, we compared specially $\mathrm{NH}_{3}$ concentrations and emission at similar ventilation rates (Table 4). In all three ventilation ranges, $\mathrm{NH}_{3}$ concentration and emission from treatment were significantly lower than in control.

Table 4. Comparison of $\mathrm{NH}_{3}$ concentrations and emissions from control and treatment rooms at similar ventilation rates.

\begin{tabular}{|c|c|c|c|c|c|c|}
\hline \multirow{2}{*}{$\begin{array}{l}\text { Ventilation Rate Range } \\
\qquad\left(\mathrm{m}^{3} \mathrm{~h}^{-1} \text { head }^{-1}\right)\end{array}$} & \multicolumn{3}{|c|}{$\mathrm{NH}_{3}$ Concentration (ppmv) } & \multicolumn{3}{|c|}{$\mathrm{NH}_{3}$ Emission $\left(\mathrm{g} \mathrm{h}^{-1}\right.$ head $\left.^{-1}\right)$} \\
\hline & Control $(n)$ & Treatment $(n)$ & $\begin{array}{c}\text { Reduction } \\
\text { Rate (\%) }\end{array}$ & Control & Treatment & $\begin{array}{c}\text { Reduction } \\
\text { Rate (\%) }\end{array}$ \\
\hline $50 \sim 55$ & $15.4 \pm 5.8^{\mathrm{a}}(33)$ & $6.6 \pm 1.7^{\mathrm{b}}(25)$ & 57.1 & $0.63 \pm 0.24^{a}$ & $0.27 \pm 0.07^{b}$ & 58.0 \\
\hline $70 \sim 78$ & $11.8 \pm 3.4^{\mathrm{a}}(138)$ & $8.8 \pm 4.0^{\mathrm{b}}(46)$ & 24.9 & $0.69 \pm 0.20^{a}$ & $0.51 \pm 0.23^{b}$ & 26.9 \\
\hline
\end{tabular}

a,b Different superscripts in the same row meaning each group are significantly different. $(p<0.05)$.

In this study, normalized $\mathrm{NH}_{3}$ and $\mathrm{H}_{2} \mathrm{~S}$ emissions with $500 \mathrm{~kg}$ live weight (AU) were 41.5, $2.1 \mathrm{~g}$ per day, respectively. $\mathrm{NH}_{3}$ emissions reported here were $\sim 4.2$ times higher than previous results (Table 1 , Table A1). The estimated $\mathrm{H}_{2} \mathrm{~S}$ emissions were higher than values reported by Lim et al. [35] and Kai et al. [34] and comparable with values reported by Blunden et al. [36], which used a commercial barn to estimate the gas emissions.

\subsection{Characteristics of Recharging Liquid and Manure}

Aerobically treated liquid manure collected on day 13 differed from the one collected on day 0 in several parameters. As shown in Table 5, electric conductivity (EC) decreased from 14.2 to $11.6 \mu \mathrm{S} \mathrm{cm}-1$. Although the total $\mathrm{N}$ contents were similar, most of the $\mathrm{N}$ was in the form of ammonium $\left(\mathrm{NH}_{4}{ }^{+}\right)$in day 0 , while the one from day 13 had less ammonium nitrogen. 
Table 5. Characteristics of recharged aerobically treated liquid manure (collected from the last stage of the aerobic treatment system, Figure 1). The samples were collected at the initial and final day of the experiment. Manure samples from the pit represent stored manure (Figure A2).

\begin{tabular}{|c|c|c|c|c|c|}
\hline \multirow{2}{*}{$\begin{array}{l}\text { Ventilation Rate Range } \\
\qquad\left(\mathrm{m}^{3} \mathrm{~h}^{-1} \mathrm{head}^{-1}\right)\end{array}$} & \multicolumn{2}{|c|}{ Aerobically Treated Liquid Manure } & \multicolumn{3}{|c|}{ Manure Sample from the Pit in Day 13} \\
\hline & Day 0 & Day 13 & Control ${ }^{1}$ & Treatment $^{2}$ & $p$-Value \\
\hline Moisture content $\left(\%\right.$, w.b. $\left.{ }^{3}\right)$ & 98.7 & 98.7 & $93.9 \pm 2.8^{\mathrm{a}}$ & $95.6 \pm 4.0^{\mathrm{a}}$ & 0.0532 \\
\hline Volatile solids $\left(\%\right.$, d. b. $\left.{ }^{4}\right)$ & 40.4 & 39.8 & $68.8 \pm 3.5^{\mathrm{a}}$ & $38.9 \pm 6.5^{b}$ & 0.0000 \\
\hline $\mathrm{pH}$ & 8.6 & 8.2 & $7.7 \pm 0.1^{\mathrm{a}}$ & $8.0 \pm 0.4^{\mathrm{a}}$ & 0.3475 \\
\hline $\mathrm{EC}^{5}\left(\mu \mathrm{S} \mathrm{cm}^{-1}\right)$ & 14.2 & 11.6 & $30.7 \pm 4.0^{\mathrm{a}}$ & $12.7 \pm 0.2^{b}$ & 0.0159 \\
\hline Total N (mg L $\left.{ }^{-1}\right)$ & 1175.8 & 1199.9 & $6037 \pm 829$ & $2207 \pm 1173^{b}$ & 0.0135 \\
\hline $\mathrm{NH}_{4}-\mathrm{N}\left(\mathrm{mg} \mathrm{L}^{-1}\right)$ & 918.2 & 216.3 & $3806 \pm 17^{a}$ & $801 \pm 304^{\mathrm{b}}$ & 0.0002 \\
\hline
\end{tabular}

${ }^{1}$ Manure from pit of control (conventional slurry pit); ${ }^{2}$ Aerobically treated liquid manure mixed with manure from pit of treatment (pit recharge system); ${ }^{3}$ wet basis; ${ }^{4}$ dry basis; ${ }^{5}$ Electric conductivity; ${ }^{a, b}$ Different superscripts in the same row mean characteristics of manure sample from control and treatment pit are significantly different.

The manure characteristics of samples collected in control and treatment pits are compared in Table 5. A mixture of aerobically treated liquid manure mixed with stored manure had higher moisture content and lower volatile solids content compared with manure from control $(p<0.05)$. The mean total $\mathrm{N}$ content in samples from treatment was $2,207 \mathrm{mg} \mathrm{L}^{-1}$, i.e., significantly lower than $6307 \mathrm{mg} \mathrm{L}^{-1}$ in samples from control $(p<0.05)$. The $\mathrm{NH}_{4}-\mathrm{N}$ content was $801 \mathrm{mg} \mathrm{L}^{-1}$, i.e., significantly lower compared with $3806 \mathrm{mg} \mathrm{L}^{-1}$ of the control $(p<0.05)$.

\section{Discussion}

\subsection{Correlation of $\mathrm{NH}_{3} \& \mathrm{H}_{2} \mathrm{~S}$ Concentration with Ventilation Rate}

In this study, the emissions of $\mathrm{NH}_{3}$ and $\mathrm{H}_{2} \mathrm{~S}$ were positively correlated with the ventilation rates in both rooms (Figures 3 and 7). However, in the case of gas concentrations, $\mathrm{NH}_{3}$ showed no correlation with the ventilation rate in both rooms $(\mathrm{R}=-0.09$ and 0.02 , in control and treatment, respectively). Also, $\mathrm{H}_{2} \mathrm{~S}$ showed a negative correlation with ventilation rates only in control (Figure 6). A more thorough analysis revealed that the properties of emitting manure near the surface in the treatment might explain these observations. Table 6 summarizes the detailed results about $\mathrm{N}$ content and the $\mathrm{pH}$ of manure sampled at three different depths of manure in each pit at day 13 . The values from treatment showed a concentration gradient by sampled depth. The $\mathrm{pH}$ was higher, and the $\mathrm{NH}_{4}-\mathrm{N}$ was lower in the (shallow) manure depth in treatment. The total $\mathrm{N}$ in shallow depth in control was $5414 \mathrm{mg} \mathrm{L}^{-1}$, (over 2.5 times higher than in treatment, $2044 \mathrm{mg} \mathrm{L}^{-1}$ ) and most of $\mathrm{N}$ existed in the form of $\mathrm{NH}_{4}$. The $\mathrm{NH}_{4}-\mathrm{N}$ in shallow depth in control was $3827 \mathrm{mg} \mathrm{L}^{-1}$ and was over 6 times higher than treatment $\left(619 \mathrm{mg} \mathrm{L}^{-1}\right)$. Taken together, the manure surface in both control and treatment (represented by shallow depth data) had plenty of total $\mathrm{N}_{\text {and }} \mathrm{NH}_{4}-\mathrm{N}$ to facilitate emissions. The $\mathrm{NH}_{4}-\mathrm{N}$ is sensitive to temperature and $\mathrm{pH}$ and can be easily converted into $\mathrm{NH}_{3}$ gas [40]. If the available $\mathrm{N}$ was identical in the control and treatment, a higher $\mathrm{pH}$ would result in higher emissions from treatment. However, the opposite effect was observed. A significant difference in $\mathrm{NH}_{3}$ emissions and a mitigation effect occurred because of the significant differences in the total $\mathrm{N}$ and $\mathrm{NH}_{4}-\mathrm{N}$ in control and treatment. This was likely the reason that the ventilation rate increase did not result in a dilution effect for $\mathrm{NH}_{3}$ concentration while other factors (e.g., $\mathrm{pH}, \mathrm{NH}_{4}-\mathrm{N}$ and the total $\mathrm{N}$ ) were offsetting any potential effect.

In contrast, slightly basic ( $\mathrm{pH}$ 7.7) manure in shallow depth of control prevented the sulfur volatilization, and the emitted $\mathrm{H}_{2} \mathrm{~S}$ was diluted by increasing ventilation rates (Figure 6). Approximately $80 \%$ of $\mathrm{H}_{2} \mathrm{~S}$ converted to HS- when the $\mathrm{pH}$ is 7.7 at $25^{\circ} \mathrm{C}$. However, in treatment ( $\mathrm{pH}$ 8.3), there was no correlation between $\mathrm{H}_{2} \mathrm{~S}$ concentration and ventilation rates. It appears that aerobically treated liquid manure in the pit was at least in part responsible for the significant reduction of $\mathrm{H}_{2} \mathrm{~S}$ emissions. The more basic $\mathrm{pH}$ (8.3) of manure in shallow depth was also helpful to reduce $\mathrm{H}_{2} \mathrm{~S}$ emissions (Tables 6 and 7). 
Table 6. Characteristics of manure collected at 3 different depths (shallow, middle, deep) of each pit (Figure A2).

\begin{tabular}{|c|c|c|c|c|c|c|c|c|}
\hline & \multicolumn{4}{|c|}{ Control $^{1}$} & \multicolumn{4}{|c|}{ Treatment $^{2}$} \\
\hline & Mean & Shallow $^{3}$ & Middle $^{4}$ & Deep $^{5}$ & Mean & Shallow $^{3}$ & Middle $^{4}$ & Deep $^{5}$ \\
\hline Moisture content (\%, w.b. $\left.{ }^{6}\right)$ & 93.9 & 96.3 & 95.2 & 90.1 & 98.5 & 98.6 & 98.3 & 89.9 \\
\hline $\mathrm{pH}$ & 7.7 & 7.7 & 7.7 & 7.6 & 8.0 & 8.3 & 8.2 & 7.5 \\
\hline $\mathrm{EC}^{8}\left(\mu \mathrm{S} \mathrm{cm} \mathrm{cm}^{-1}\right)$ & 30.7 & 33.2 & 32.8 & 26.1 & 12.7 & 12.9 & 12.7 & 12.6 \\
\hline
\end{tabular}

${ }^{1}$ Manure from the pit of control (conventional slurry pit); ${ }^{2}$ Aerobically treated liquid manure mixed with manure from the pit of treatment (pit recharge system); ${ }^{3} 60 \mathrm{~cm}$ from the bottom; ${ }^{4} 40 \mathrm{~cm}$ from the bottom; ${ }^{5} 20 \mathrm{~cm}$ from the bottom ${ }^{6}$ wet basis; ${ }^{7}$ dry basis; ${ }^{8}$ Electric conductivity.

Table 7. Percent of $\mathrm{H}_{2} \mathrm{~S}$ and $\mathrm{HS}^{-}\left(\mathrm{H}_{2} \mathrm{~S} / \mathrm{HS}^{-}\right.$equilibrium) in different $\mathrm{pH}$ of liquid at $25^{\circ} \mathrm{C}$.

\begin{tabular}{ccc}
\hline \multirow{2}{*}{$\mathbf{H}$} & \multicolumn{2}{c}{ Fraction Present (\%) } \\
\cline { 2 - 3 } & $\mathbf{H}_{\mathbf{2}} \mathbf{S}$ & $\mathbf{H S}^{-}$ \\
\hline 7.7 (Control) & 17.95 & 82.05 \\
8.3 (Treatment) & 5.21 & 94.79 \\
\hline
\end{tabular}

\section{2. $\mathrm{NH}_{3} \mathcal{E} \mathrm{H}_{2} \mathrm{~S}$ Concentration and Emission Rates in the Pit Recharge System}

The pit recharge system showed a significant reduction in $\mathrm{NH}_{3}(32.6 \%)$ and $\mathrm{H}_{2} \mathrm{~S}(78.3 \%)$ concentrations. That reduction of gas concentrations is beneficial to improve indoor air quality and working environment for farmers. Further research in the effects of improved air quality on the productivity of pigs is warranted. Although the reduction rate of $\mathrm{NH}_{3}$ and $\mathrm{H}_{2} \mathrm{~S}$ emissions by pit recharge system were $47.8 \%$ and $82.3 \%$, respectively, the actual gas emissions in this study were greater than previous studies with pit recharge system (Table A2). We hypothesize that one of the reasons was due to the $17.5 \%$ crude protein content in the feed, which was greater than generally recommended in feeding standard in other countries (Table 8). Generally, $\sim 20 \%$ more $\mathrm{NH}_{3}$ is produced per $1 \%$ point of crude protein increase [41]. Based on the simple calculation, 31-124\% more $\mathrm{NH}_{3}$ would be produced compared with that reported by Lim et al. [35] and Kai et al. [34], due to the 1.5-6\%-point higher crude protein. This is consistent with measured $\mathrm{NH}_{3}$ concentrations (Table A2).

Table 8. Comparison of crude protein contents in feed and previously recommended crude protein contents by feeding standard.

\begin{tabular}{cc}
\hline & Crude Protein in the Feed (\%, d.b. ${ }^{\mathbf{1}}$ ) \\
\hline JRC (2005) ${ }^{1}$ & 13.0 \\
SCA (1987) & ${ }^{2}$ \\
Lim et al. (2004) [35] & 15.0 \\
Kai et al. (2006) [34] & $11.5 \sim 13.1$ \\
This study & 16.0 \\
\hline
\end{tabular}

${ }^{1}$ Agriculture, Forestry and Fisheries Research Council Secretariat of Japan; ${ }^{2}$ Standing Committee on Agriculture in Australia.

\subsection{Characteristics of Recharging Liquid and Manure}

During 14 days of the experiment, the changes of $\mathrm{N}$ species (forms) in aerobically treated liquid manure was observed (Table 5). The total $\mathrm{N}$ contents of day 0 and day 13 were very similar, but most of $\mathrm{N}$ was in the form of $\mathrm{NH}_{4}$ on day 0 while the $\mathrm{NH}_{4}-\mathrm{N}$ concentration was low at day 13. During the aerobic treatment, the organic $\mathrm{N}$ in manure converts to $\mathrm{NH}_{4}$ by mineralization. If more aeration is available, the $\mathrm{NH}_{4}$ converts to $\mathrm{NO}_{3}$ (a stable $\mathrm{N}$ form by nitrification) and $\mathrm{pH}$ decreases. Therefore, 
it is expected that it will be possible to control the $\mathrm{NH}_{3}$ and $\mathrm{H}_{2} \mathrm{~S}$ emission rates by controlling the nitrification level of the liquid manure by (e.g.,) aeration rate in the aerobic treatment system.

It is also important to consider the mass balance of $\mathrm{N}$ and $\mathrm{S}$ in a pit recharge system. This paper reported a significant improvement to air quality (i.e., lower gas concentrations) inside the barn and significantly lower emissions from the barn. However, it is reasonable to expect $\mathrm{NH}_{3}$ and $\mathrm{H}_{2} \mathrm{~S}$ emissions from liquid-solids separation, and liquid manure aerobic treatment system. Comparing the total $\mathrm{N}$ contents of aerobically treated liquid manure and manure from the control pit shows that about $80 \%$ of $\mathrm{N}$ was lost during the aerobic treatment of swine manure (Table 5).

The centralized manure plants, e.g., like the one that treats manure from conventional storage at this tested farm, have mandatory deodorization systems for treating emissions. For example, the two stages of liquid manure aeration areas are covered, and odorous air is treated by a wet scrubber before emitted to the atmosphere. Also, odorous air from solid-liquid separation and solid composting are also treated by the same wet scrubber. Thus, the technology to treat gaseous emissions on a large centralized manure plant scale is in place. However, the economic feasibility of installing such treatment on a farm scale needs to be evaluated.

\section{Conclusions}

The evaluation of a semi-continuous pit recharge system on the mitigation of ammonia $\left(\mathrm{NH}_{3}\right)$ and hydrogen sulfide $\left(\mathrm{H}_{2} \mathrm{~S}\right)$ emissions from a swine finisher barn was conducted for two weeks at a commercial swine farm in the Republic of Korea. Gas concentrations and emissions from a room equipped with a pit recharge system were compared with a room operating conventional slurry pit under the slatted floor. Mean reduction of $\mathrm{NH}_{3}$ and $\mathrm{H}_{2} \mathrm{~S}$ emissions were $49 \pm 6 \%(p=0.0001)$ and $82 \pm 7 \%(p<0.0000)$, respectively. The removal efficiency of $\mathrm{H}_{2} \mathrm{~S}$ was higher than $\mathrm{NH}_{3}$ likely because the $\mathrm{pH}$ of aerobically treated liquid manure remained slightly above 8 . It is also expected that it will be possible to control the $\mathrm{NH}_{3}$ and $\mathrm{H}_{2} \mathrm{~S}$ removal rates by controlling the nitrification level of the liquid manure in the aerobic treatment system. More work is warranted to assess the $\mathrm{N}$ balance in this system, and emissions of odor and GHGs. The economic feasibility of installing and maintaining such treatment on a farm scale and possible effects on animal productivity needs to be evaluated.

Author Contributions: Conceptualization, H.A.; methodology, H.A.; validation, J.W., J.A.K. and H.A.; formal analysis, J.W.; investigation, J.W., S.L., E.K., M.L.; resources, S.L., E.K., M.L. and H.A.; data curation, J.W.; writing-original draft preparation, J.W.; writing-review and editing, J.W., J.A.K., and H.A.; visualization, J.W.; supervision, H.A. and J.A.K.; project administration, H.A.; funding acquisition, H.A.

Funding: This research was supported by Korea Institute of Planning and Evaluation for Technology in Food, Agriculture, Forestry and Fisheries (IPET) through Agri-Bio Industry Technology Development Program, funded by Ministry of Agriculture, Food and Rural Affairs (MAFRA) (Grant No. 317008-3). This project was partially supported by the Iowa Agriculture and Home Economics Experiment Station, Ames, Iowa. Project No. IOW05556 (Future Challenges in Animal Production Systems: Seeking Solutions through Focused Facilitation) is sponsored by Hatch Act and State of Iowa funds.

Acknowledgments: This authors gratefully acknowledge Seongyoong Cho (Nagwon Chuksan, Swine Farm) and Jongkook Lee (EcoViron Company) for providing experimental swine farm and pit recharge system. Special thanks to Woosang Lee (Smart Control \& Sensing Inc.) for his help with gas monitoring.

Conflicts of Interest: The authors declare no conflict of interest. The funders had no role in the design of the study; in the collection, analyses, or interpretation of data; in the writing of the manuscript, or in the decision to publish the results. 


\section{Appendix A}

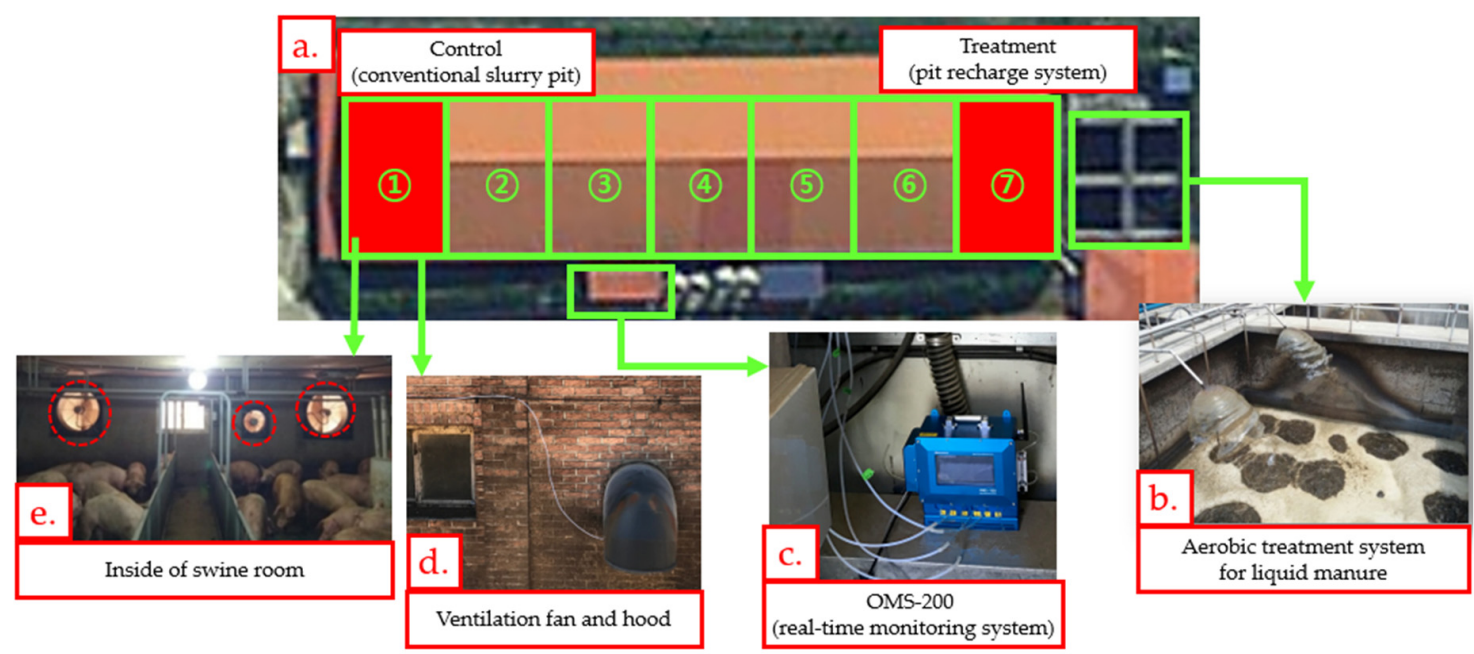

Figure A1. Pictures of experimental site. From top clockwise: a. Satellite photo swine barn with marked control \& treatment rooms (rooms 1 to 3 operate conventional slurry pits, 5 to 7 operate pit recharge, 4 could be used in both modes), b. Location of the outdoor aerobic treatment system for liquid manure; view of manure spray nozzles discharging into the liquid manure treatment system for minimizing foam generation from aeration, c. Real-Time gas and ventilation rate monitor, d. Primary fan with the downward pointed cone, air sampling line visible to the left of fan cone, e. interior of swine barn.

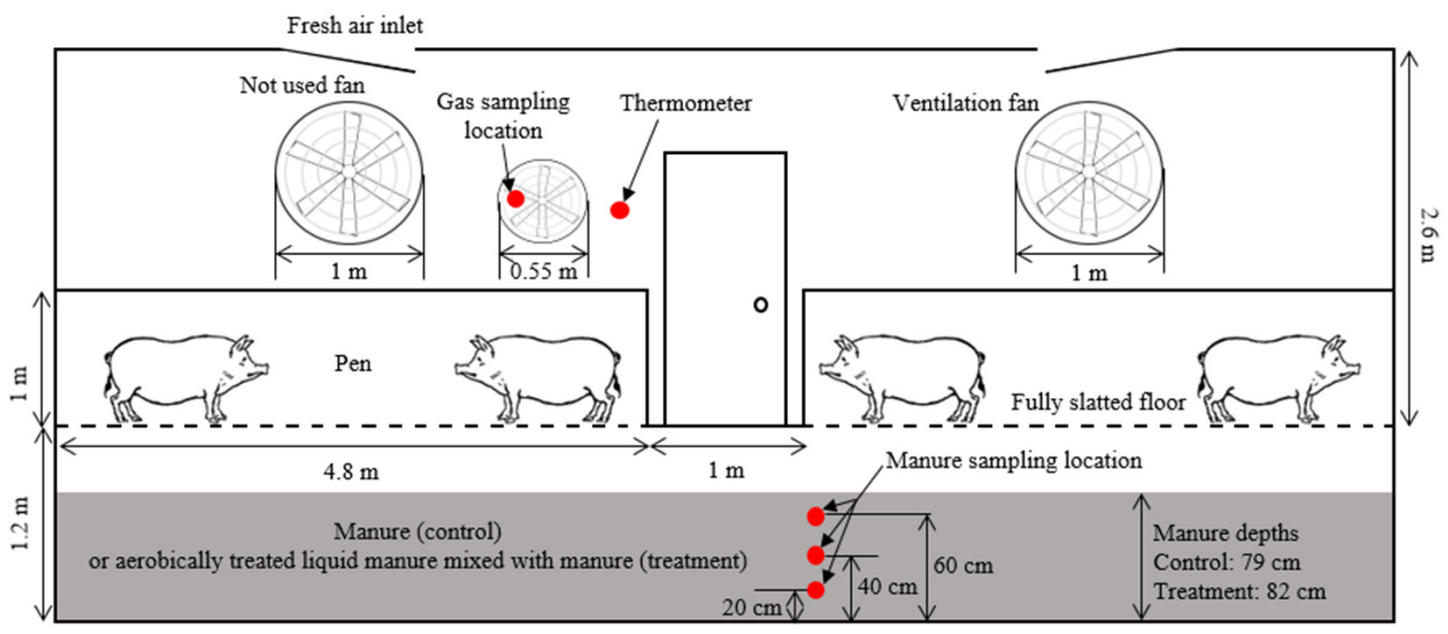

Figure A2. Side view of tested swine rooms (control and treatment). The gas sampling port was positioned immediately downstream from a primary fan (operating at all-times). The thermometer was installed near the fan. The manure was sampled from the middle of the pit. 


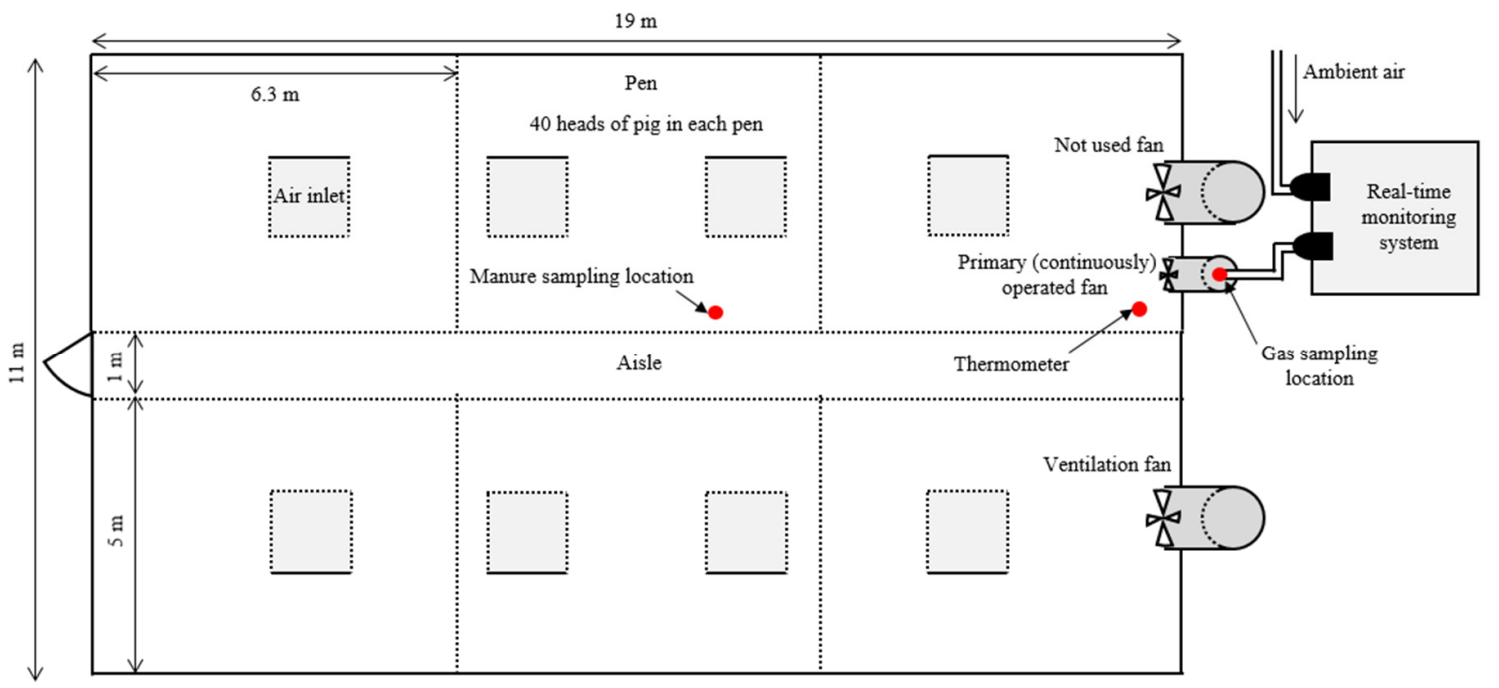

Figure A3. Top view of tested swine room.

Table A1. Specifications of gas sensors (Membrapor Co.) used in this study.

\begin{tabular}{ccc}
\hline & $\mathbf{N H}_{\mathbf{3}}$ & $\mathbf{H}_{\mathbf{2}} \mathbf{S}$ \\
\hline Model & $\mathrm{NH} 3 / \mathrm{CR}-50$ & $\mathrm{H} 2 \mathrm{~S} / \mathrm{C}-50$ \\
Detecting range & $0-50 \mathrm{ppm}$ & $0-50 \mathrm{ppm}$ \\
Resolution & $0.5 \mathrm{ppm}$ & $50 \mathrm{ppb}$ \\
Linearity $\left(\mathrm{R}^{2}\right)$ & 0.9951 & 0.9995 \\
\hline
\end{tabular}

Table A2. Comparison of $\mathrm{NH}_{3}$ and $\mathrm{H}_{2} \mathrm{~S}$ emissions with previous literature.

\begin{tabular}{|c|c|c|c|}
\hline Study & Recharging Liquid & $\begin{array}{l}\text { Recharging } \\
\text { Frequency }\end{array}$ & $\begin{array}{c}\text { Gas Emission Rate } \\
\left(\mathrm{g} \mathrm{d}^{-1} \mathrm{AU}^{-1}\right)\end{array}$ \\
\hline \multirow{3}{*}{ Lim et al. (2004) [35] } & \multirow{3}{*}{ Lagoon effluent } & $1 \mathrm{wk}$ & $\begin{array}{l}\mathrm{NH}_{3} ; 10 \\
\mathrm{H}_{2} \mathrm{~S} ; 0.16\end{array}$ \\
\hline & & 2 wks & $\begin{array}{l}\mathrm{NH}_{3} ; 12 \\
\mathrm{H}_{2} \mathrm{~S} ; 0.34\end{array}$ \\
\hline & & 6 wks & $\begin{array}{c}\mathrm{NH}_{3} ; 11 \\
\mathrm{H}_{2} \mathrm{~S} ; 1.42\end{array}$ \\
\hline Kai et al. (2006) [34] & Water & $1 \mathrm{wk}$ & $\mathrm{NH}_{3} ; 17 \sim 23$ \\
\hline \multirow{4}{*}{ Blunden et al. (2008) [36] } & \multirow{3}{*}{ Lagoon effluent } & $1 \mathrm{wk}$ & $\begin{array}{c}\mathrm{NH}_{3} ; 40.8 \\
\mathrm{H}_{2} \mathrm{~S} ; 4.2\end{array}$ \\
\hline & & $1 \mathrm{wk}$ & $\begin{array}{c}\mathrm{NH}_{3} ; 37.1 \\
\mathrm{H}_{2} \mathrm{~S} ; 3.3\end{array}$ \\
\hline & & $1 \mathrm{wk}$ & $\begin{array}{c}\mathrm{NH}_{3} ; 29.5 \\
\mathrm{H}_{2} \mathrm{~S} ; 1.2\end{array}$ \\
\hline & & $1 \mathrm{wk}$ & $\begin{array}{c}\mathrm{NH}_{3} ; 14.3 \\
\mathrm{H}_{2} \mathrm{~S} ; 1.7\end{array}$ \\
\hline This study & $\begin{array}{l}\text { Aerobically treated } \\
\text { liquid manure }\end{array}$ & 3 times $\mathrm{d}^{-1}$ & $\begin{array}{l}\mathrm{NH}_{3} ; 41.5 \\
\mathrm{H}_{2} \mathrm{~S} ; 2.1\end{array}$ \\
\hline
\end{tabular}

\section{References}

1. Lo, Y.C.M.; Koziel, J.A.; Cai, L.; Hoff, S.J.; Jenks, W.S.; Xin, H. Simultaneous chemical and sensory characterization of volatile organic compounds and semi-volatile organic compounds emitted from swine manure using solid phase microextraction and multidimensional gas chromatography-mass spectrometry-olfactometry. J. Environ. Qual. 2008, 37, 521-534. [CrossRef]

2. Buijsman, E.; Erisman, J.W. Wet deposition of ammonium in Europe. J. Atmos. Chem. 1988, 6, 265-280. [CrossRef] 
3. Oenema, O.; Velthof, G.; Klimont, Z.; Winiwarter, W. Emissions from Agriculture and Their Control Potentials; TSAP Report \#3. IIASA; IIASA: Laxenburg, Austria, 2012. Available online: http://ec.europa.eu/ environment/air/pdf/TSAP-AGRI-20121129_v21.pdf (accessed on 28 March 2019).

4. Cai, L.; Koziel, J.; Lo, Y.; Hoff, S.J. Characterization of VOCs and odorants associated with swine barn particulate matter using SPME and gas chromatography-mass spectrometry-olfactometry. J. Chromatogr. A. 2006, 1102, 60-72. [CrossRef]

5. Kim, K.Y.; Ko, H.J.; Kim, H.T.; Kim, Y.S.; Roh, Y.M.; Lee, C.M.; Kim, C.N. Quantification of ammonia and hydrogen sulfide emitted from pig buildings in Korea. J. Environ. Manag. 2008, 88, 195-202. [CrossRef] [PubMed]

6. Schiffman, S.S. Livestock odors: Implications for human health and well-being. J. Anim. Sci. 1998, 76, 1343-1355. [CrossRef] [PubMed]

7. Ni, J.-Q.; Heber, A.J.; Diehl, C.A.; Lim, T.T. SE—Structures and environment: Ammonia, hydrogen sulphide and carbon dioxide release from pig manure in under-floor deep pits. J. Agric. Eng. Res. 2000, 77, 53-66. [CrossRef]

8. Rahman, S.; Borhan, M.S. Typical odor mitigation technologies for swine production facilities: A review. J. Civ. Environ. Eng. 2012, 2, 117. [CrossRef]

9. Akdeniz, N.; Jacobson, L.D.; Hetchler, B.P.; Bereznicki, S.D.; Heber, A.J.; Koziel, J.A.; Cai, L.; Zhang, S.; Parker, D.B. Odor and odorous chemical emissions from animal buildings: Part 2. Odor emissions. Trans. ASABE 2012, 55, 2335-2345. [CrossRef]

10. Bereznicki, S.D.; Heber, A.J.; Akdeniz, N.; Jacobson, L.D.; Hetchler, B.P.; Heathcote, K.Y.; Hoff, S.J.; Koziel, J.A.; Cai, L.; Zhang, S. Odor and odorous chemical emissions from animal buildings: Part 1. Project overview, collection methods, and quality control. Trans. ASABE 2012, 55, 2325-2334. [CrossRef]

11. Cai, L.; Koziel, J.A.; Zhang, S.; Heber, A.J.; Cortus, E.L.; Parker, D.B.; Hoff, S.J.; Sun, G.; Heathcote, K.Y.; Jacobson, L.D. Odor and odorous chemical emissions from animal buildings: Part 3. Chemical emissions. Trans. ASABE 2015, 58, 1333-1347. [CrossRef]

12. Heber, A.J.; Ni, J.-Q.; Lim, T.T.; Tao, P.-C.; Schmidt, A.M.; Koziel, J.A.; Beasley, D.B.; Hoff, S.J.; Nicolai, R.E.; Jacobson, L.D. Quality assured measurements of animal building emissions: Gas concentrations. J. Air Waste Manag. Assoc. 2006, 56, 1472-1483. [CrossRef] [PubMed]

13. Parker, D.B.; Perschbacher-Buser, Z.L.; Cole, N.A.; Koziel, J.A. Recovery of agricultural odors and odorous compounds from polyvinyl fluoride film bags. Sensors 2010, 10, 8536-8552. [CrossRef] [PubMed]

14. Zhang, S.; Koziel, J.A.; Cai, L.; Hoff, S.J.; Heathcote, K.Y.; Chen, L.; Jacobson, L.D.; Akdeniz, N.; Hetchler, B.P.; Parker, D.B. Odor and odorous chemical emissions from animal buildings: Part 5. Simultaneous chemical and sensory analysis with gas chromatography-mass spectrometry-olfactometry. Trans. ASABE 2015, 58, 1349-1359. [CrossRef]

15. Hoff, S.J.; Bundy, D.S.; Nelson, M.A.; Zelle, B.C.; Jacobson, L.D.; Heber, A.J.; Ni, J.; Zhang, Y.; Koziel, J.A.; Beasley, D.B. Emissions of ammonia, hydrogen sulfide, and odor before, during, and after slurry removal from a deep-pit swine finisher. J. Air Waste Manag. Assoc. 2006, 56, 581-590. [CrossRef]

16. Koziel, J.; Spinhirne, J.; Lloyd, J.; Parker, D.; Wright, D.; Kuhrt, F. Evaluation of sample recoveries of malodorous gases for odor bags, SPME, air sampling canisters, and sorbent tubes. J. Air Waste Manag. Assoc. 2005, 55, 1147-1157. [CrossRef] [PubMed]

17. Zhu, W.; Koziel, J.A.; Cai, L.; Wright, D.; Kuhrt, F. Testing odorants recovery from a novel metallized fluorinated ethylene propylene gas sampling bag. J. Air Waste Manag. Assoc. 2015, 65, 1434-1445. [CrossRef]

18. Maurer, D.L.; Bragdon, A.M.; Short, B.C.; Ahn, H.; Koziel, J.A. Improving environmental odor measurements: Comparison of lab-based standard method and portable odor measurement technology. Arch. Environ. Prot. 2018, 44. [CrossRef]

19. Gay, S.; Schmidt, D.; Clanton, C.; Janni, K.; Jacobson, L.; Weisberg, S. Odor, total reduced sulfur, and ammonia emissions from animal housing facilities and manure storage units in Minnesota. Appl. Eng. Agric. 2003, 19, 347. [CrossRef]

20. Maurer, D.L.; Koziel, J.A.; Harmon, J.D.; Hoff, S.J.; Rieck-Hinz, A.M.; Andersen, D.S. Summary of performance data for technologies to control gaseous, odor, and particulate emissions from livestock operations: Air management practices assessment tool (AMPAT). Data Br. 2016, 7, 1413-1429. [CrossRef]

21. Van der Heyden, C.; Demeyer, P.; Volcke, E.I. Mitigating emissions from pig and poultry housing facilities through air scrubbers and biofilters: State-of-the-art and perspectives. Biosyst. Eng. 2015, 134, 74-93. [CrossRef] 
22. Chen, L.; Hoff, S.; Cai, L.; Koziel, J.; Zelle, B.; Association, W.M. Evaluation of wood chip-based biofilters to reduce odor, hydrogen sulfide, and ammonia from swine barn ventilation air. J. Air Waste Manag. Assoc. 2009, 59, 520-530. [CrossRef]

23. Chen, L.; Hoff, S.J.; Koziel, J.A.; Cai, L.; Zelle, B.; Sun, G. Performance evaluation of a wood-chip based biofilter using solid-phase microextraction and gas chromatography-mass spectroscopy-olfactometry. Bioresour. Technol. 2008, 99, 7767-7780. [CrossRef]

24. Zhu, W.; Koziel, J.A.; Maurer, D.L. Mitigation of livestock odors using black light and a new titanium dioxide-based catalyst: Proof-of-concept. Atmosphere 2017, 8, 103. [CrossRef]

25. Maurer, D.; Koziel, J.A. On-farm pilot-scale testing of black ultraviolet light and photocatalytic coating for mitigation of odor, odorous VOCs, and greenhouse gases. Chemosphere 2019, 221, 778-784. [CrossRef]

26. Maurer, D.L.; Koziel, J.A.; Kalus, K.; Andersen, D.S.; Opalinski, S. Pilot-scale testing of non-activated biochar for swine manure treatment and mitigation of ammonia, hydrogen sulfide, odorous volatile organic compounds (VOCs), and greenhouse gas emissions. Sustainability 2017, 9, 929. [CrossRef]

27. Maurer, D.L.; Koziel, J.A.; Bruning, K.; Parker, D.B. Farm-scale testing of soybean peroxidase and calcium peroxide for surficial swine manure treatment and mitigation of odorous VOCs, ammonia and hydrogen sulfide emissions. Atmos. Environ. 2017, 166, 467-478. [CrossRef]

28. Maurer, D.L.; Koziel, J.A.; Bruning, K.; Parker, D.B. Pilot-scale testing of renewable biocatalyst for swine manure treatment and mitigation of odorous VOCs, ammonia and hydrogen sulfide emissions. Atmos. Environ. 2017, 150, 313-321. [CrossRef]

29. Cai, L.; Koziel, J.A.; Liang, Y.; Nguyen, A.T.; Xin, H. Evaluation of zeolite for control of odorants emissions from simulated poultry manure storage. J. Environ. Qual. 2007, 36, 184-193. [CrossRef] [PubMed]

30. Kalus, K.; Opaliński, S.; Maurer, D.; Rice, S.; Koziel, J.A.; Korczyński, M.; Dobrzański, Z.; Kołacz, R.; Gutarowska, B. Odour reducing microbial-mineral additive for poultry manure treatment. Front. Environ. Sci. Eng. 2017, 11, 7. [CrossRef]

31. Mackie, R.I.; Stroot, P.G.; Varel, V.H. Biochemical identification and biological origin of key odor components in livestock waste. J. Anim. Sci. 1998, 76, 1331-1342. [CrossRef]

32. Arogo, J.; Westerman, P.; Heber, A.J. A review of ammonia emissions from confined swine feeding operations. Trans. ASAE 2003, 46, 805. [CrossRef]

33. Maurer, D.L.; Koziel, J.A.; Bruning, K. Field scale measurement of greenhouse gas emissions from land applied swine manure. Front. Environ. Sci. Eng. 2017, 11, 1. [CrossRef]

34. Kai, P.; Kaspers, B.; Van Kempen, T. Modeling sources of gaseous emissions in a pig house with recharge pit. Trans. ASABE 2006, 49, 1479-1485. [CrossRef]

35. Lim, T.T.; Heber, A.J.; Ni, J.Q.; Kendall, D.C.; Richert, B.R. Effects of manure removal strategies on odor and gas emissions from swine finishing. Trans. ASAE 2004, 47, 2041-2050. [CrossRef]

36. Blunden, J.; Aneja, V.P.; Westerman, P.W. Measurement and analysis of ammonia and hydrogen sulfide emissions from a mechanically ventilated swine confinement building in North Carolina. Atmos. Environ. 2008, 42, 3315-3331. [CrossRef]

37. Ha, D.; Kim, D. The effect of liquid manure circulation system on the odor reduction of swine swine farm. J. Agric. Life Sci. 2015, 49, 57-64. [CrossRef]

38. Strobel, B.; Oertwig, T.; Paulsen, B.; Harmon, J.D. Daily cleaning options for sloped manure pits in swine finishing. In Proceedings of the 2009 ASABE Annual Meeting, Reno, Nevada, 21-24 June 2009; p. 096307. [CrossRef]

39. Ahn, H.K.; Choi, H.L. Piggery slurry composting using batch operating autothermal thermophilic aerobic digestion system. Asian-Australas. J. Anim. Sci. 2005, 19, 273-279. [CrossRef]

40. Koziel, J.A.; Frana, T.S.; Ahn, H.; Glanville, T.D.; Nguyen, L.T.; van Leeuwen, J.H. Efficacy of $\mathrm{NH}_{3}$ as a secondary barrier treatment for inactivation of Salmonella Typhimurium and methicillin-resistant Staphylococcus aureus in digestate of animal carcasses: Proof-of-concept. PLoS ONE 2017, 12, e0176825. [CrossRef] [PubMed]

41. Powers, W.; Zamzow, S.; Kerr, B.J. Reduced crude protein effects on aerial emissions from swine. Appl. Eng. Agric. 2007, 23, 539-546. [CrossRef]

(C) 2019 by the authors. Licensee MDPI, Basel, Switzerland. This article is an open access article distributed under the terms and conditions of the Creative Commons Attribution (CC BY) license (http://creativecommons.org/licenses/by/4.0/). 